\title{
Enhancement of hypoxia-activated prodrug TH-302 anti-tumor activity by Chk1 inhibition
}

\author{
Fanying Meng*, Deepthi Bhupathi, Jessica D Sun, Qian Liu, Dharmendra Ahluwalia, Yan Wang, \\ Mark D Matteucci and Charles P Hart
}

\begin{abstract}
Background: The hypoxia-activated prodrug $\mathrm{TH}-302$ is reduced at its nitroimidazole group and selectively under hypoxic conditions releases the DNA cross-linker bromo-isophosphoramide mustard (Br-IPM). Here, we have explored the effect of Chk1 inhibition on TH-302-mediated pharmacological activities.

Methods: We employed in vitro cell viability, DNA damage, cellular signaling assays and the in vivo HT29 human tumor xenograft model to study the effect of Chk1 inhibition on TH-302 antitumor activities.

Results: TH-302 cytotoxicity is greatly enhanced by Chk1 inhibition in p53-deficient but not in p53-proficient human cancer cell lines. Chk1 inhibitors reduced TH-302-induced cell cycle arrest via blocking TH-302-induced decrease of phosphorylation of histone $\mathrm{H} 3$ and increasing Cdc2-Y15 phosphorylation. Employing the single-cell gel electrophoresis (comet) assay, we observed a potentiation of the $\mathrm{TH}-302$ dependent tail moment. $\mathrm{TH}-302$ induced $\mathrm{\gamma H} 2 \mathrm{AX}$ and apoptosis were also increased upon the addition of Chk1 inhibitor. Potentiation of TH-302 cytotoxicity by Chk1 inhibitor was only observed in cell lines proficient in, but not deficient in homology-directed DNA repair. We also show that combination treatment led to lowering of Rad51 expression levels as compared to either agent alone. In vivo data demonstrate that Chk1 inhibitor enhances TH-302 anti-tumor activity in p53 mutant HT-29 human tumor xenografts, supporting the hypothesis that these in vitro results can translate to enhanced in vivo efficacy of the combination.

Conclusions: TH-302-mediated in vitro and in vivo anti-tumor activities were greatly enhanced by the addition of Chk1 inhibitors. The preclinical data presented in this study support a new approach for the treatment of p53-deficient hypoxic cancers by combining Chk1 inhibitors with the hypoxia-activated prodrug $\mathrm{TH}-302$.
\end{abstract}

Keywords: Cancer, Hypoxia, Chk1 inhibitor, Hypoxia-activated prodrug, DNA damage, DNA repair, in vitro cytotoxicity, in vivo anti-tumor activity, Xenograft models

\section{Background}

Hypoxia in solid tumors and the affected bone marrow of hematologic malignancies is a prevalent feature of cancer. Cells in the hypoxic tumor microenvironment are more resistant to radiotherapy and to most antiproliferative cancer drugs, and also acquire a more malignant and metastatic phenotype [1]. One therapeutic approach being developed for the treatment of cancer is hypoxia-activated cytostatic or cytotoxic prodrugs [2].

TH-302 is a hypoxia-activated prodrug of bromoisophosphoramide (Br-IPM) that is reduced at its 2-

\footnotetext{
* Correspondence: fmeng@thresholdpharm.com

Threshold Pharmaceuticals, 170 Harbor Way, Suite 300, South San Francisco, CA 94080-6108, USA
}

nitroimidazole group and selectively activated under the severe hypoxic conditions commonly found in tumors, but not typically observed in normal tissues [3]. Br-IPM is a potent DNA alkylating agent, and kills tumor cells by creating DNA crosslinks [4]. Preclinical data demonstrate that TH-302 exhibits anti-tumor activity both as a monotherapy as well as in combination with other cancer therapies [5-7]. Clinically, TH-302 has been investigated in several early stage trials [8-11] and is currently being evaluated in Phase III trials in soft-tissue sarcoma in combination with doxorubicin and pancreatic cancer in combination with gemcitabine (NCT01440088 and NCT01746979, respectively). 
There are two major cell-cycle checkpoint systems for detecting and responding to DNA damage: the $G_{1} / S$ and intra-S checkpoints system to prevent the replication of damaged DNA, and the $G_{2} / M$ checkpoint to prevent segregation of damaged chromosomes. The majority of tumors are deficient in the $G_{1} / S$ DNA damage checkpoint due to tumor suppressor p53 mutations. Pharmacological inhibition of the remaining intact $G_{2} / M$ checkpoint, e.g. through Chk1 inhibition, should lead to enhanced tumor cell death, as compared with p53 proficient normal tissue [12]. It has been shown that inhibition of Chk1 signaling using small molecule inhibitors, dominant negative constructs, interference RNA (RNAi), or ribozymes leads to abrogation the $G_{2} / M$ checkpoint, impaired DNA repair, sensitization of p53-deficient cells to apoptosis, and an increase in tumor cell death [13-15]. Of particular note, Chk1 inhibitors have also been designed as prodrugs for selective activation in the hypoxic regions of tumors $[15,16]$.

Chk1 also regulates homology-directed repair (HDR), as DNA damage-induced HDR is dependent on Chk1mediated Rad51 phosphorylation. Chk1 inhibition leads to impaired Rad51 foci formation, a key step in HDR $[17,18]$. Abrogation of Chk1 function leads to persistent unrepaired DNA double-strand breaks (DSBs). Chk1 inhibition results in premature mitotic entry in response to DNA damaging agents thus resulting in increased phosphorylated histone $\mathrm{H} 3$, a marker of mitosis [19]. In addition, Chk1 pathway plays an important role in protecting cells from caspase-3-mediated apoptosis [20,21]. Reports have shown that cells with reduced levels of Chk1 were found to be more prone to apoptosis $[14,21,22]$. More recently, it has been reported that Chk1 may have prognostic and predictive significance in breast cancer [23].

Chk1 inhibition can potentiate the cytotoxicity of radiation and genotoxic therapies [24-29]. Chk1 inhibitors have been widely studied and a select number of compounds have reached early clinical trials. Notable among these are the ATP-competitive inhibitors LY2603618, PF477736, AZD7762, SCH90077617, and LY260636818 [5], the latter three of which have progressed to Phase II clinical trials. Here we describe the combination therapeutic efficacy profile of Chk1 inhibitors with the hypoxia-activated prodrug $\mathrm{TH}-302$ in in vitro and in vivo preclinical models.

\section{Methods}

\section{Reagents and cell lines}

TH-302 was from Syngene, AZD7762 and LY2603618 were from Selleck Chemicals, and PF477736 was from Tocris Bioscience. RIPA was from Sigma. Protease inhibitor cocktails were from Thermo Scientific. ChemiGlow substrate was from Proteinsimple. ECL reagent,
Rad51 mAb, actin mAb, goat anti-rabbit HRP, goat antimouse HRP, and cell cycle reagents were from EMD Millipore. $\gamma \mathrm{H} 2 \mathrm{AX}$ mAb was from Epitomics. Antibodies against phospho-Histone H3, phospho-Cdc2 Y15 antibody, total Chk1, phospho-Chk1 (S296) were from Cell Signaling. Total Cdc2 p34 antibody was from Santa Cruz Biotechnology. FITC-conjugated goat anti-mouse secondary antibody and AlamarBlue cell viability reagent were from Life Technologies. Comet assay kit was from Trevigen. Caspase Glo 3/7 assay system was from Promega. Isogenic p53 proficient and deficient cell line pairs were from Horizon Discovery. All other cell lines were from ATCC.

\section{In vitro proliferation}

Exponentially growing cells were seeded $24 \mathrm{~h}$ prior to addition of test compounds. After compound addition, the plates were incubated for $2 \mathrm{~h}$ under either normoxia $\left(21 \% \mathrm{O}_{2}\right)$ or hypoxia $\left(\mathrm{N}_{2}\right)$ supplied with $5 \% \mathrm{CO}_{2}$ at $37^{\circ} \mathrm{C}$. After wash, cells were cultured for an additional $70 \mathrm{~h}$ in fresh medium containing Chk1 inhibitors under normoxia $\left(21 \% \mathrm{O}_{2}\right)$, and the viable cells were quantified using either AlamarBlue or ATP assay and normalized using either vehicle for single treatment or Chk1 inhibitor alone for combination treatment. $\mathrm{IC}_{50}$ was calculated using Prism software. The level of synergism by the Chou-Talalay method was expressed as the Combination Index (CI) calculated using CalcuSyn software [30].

\section{Cell cycle analysis}

Cells were treated with $0.1 \mu \mathrm{M}$ of either PF477736 or AZD7762 and TH-302 for $2 \mathrm{~h}$ under either normoxia $\left(21 \% \mathrm{O}_{2}\right)$ or hypoxia $\left(\mathrm{N}_{2}\right)$. Following wash, cells were cultured for additional $22 \mathrm{~h}$ in the presence of Chk1 inhibitor under normoxia. Cells were fixed in $75 \%$ ethanol and cell cycle distribution was determined using Cell Cycle reagent and Guava flow cytometry (EMD Millipore).

\section{Single cell gel electrophoresis comet assay}

After seeding cells for $24 \mathrm{~h}, \mathrm{TH}-302$ and $0.1 \mu \mathrm{M}$ of AZD7762 were added and incubated for $24 \mathrm{~h}$ under either normoxia $\left(\begin{array}{llll}21 \% & \mathrm{O}_{2}\end{array}\right)$ or hypoxia $\left(\begin{array}{lll}0.1 \% & \mathrm{O}_{2}\end{array}\right)$. For cross-linking assessment experiments, cells were treated with $20 \mu \mathrm{M}$ of bleomycin for $1 \mathrm{~h}$ starting at the end of the TH-302 treatment period. Comet assay was performed with Trevigen's single-cell electrophoresis system. The data was analyzed using Comet Assay IV software from Perceptive Instruments.

\section{Detection of $\mathrm{\gamma H} 2 \mathrm{AX}$}

HT29 colon cancer cells were treated with vehicle or TH302 for $2 \mathrm{~h}$ under either normoxia $\left(21 \% \mathrm{O}_{2}\right)$ or hypoxia $\left(\mathrm{N}_{2}\right)$ conditions with or without $0.1 \mu \mathrm{M}$ of AZD7762, and then continuously incubated for additional $4 \mathrm{~h}$ in the 
presence of AZD7762 for the combination group and AZD7762 monotherapy group. Cells were permeabilized with $1 \%$ Triton X-100 and incubated with $\gamma \mathrm{H} 2 \mathrm{AX}$ monoclonal antibody for $2 \mathrm{~h}$ and goat anti-mouse-FITC for $1 \mathrm{~h}$. Cells were imaged using a Nikon TS-100 fluorescent microscope.

\section{Caspase activity}

HT-29 cells were exposed to TH-302 and $0.1 \mu \mathrm{M}$ of AZD7762 for $2 \mathrm{~h}$ under either normoxia $\left(21 \% \mathrm{O}_{2}\right)$ or hypoxia $\left(\mathrm{N}_{2}\right)$. After wash, cells were continuously cultured for additional $46 \mathrm{~h}$ in the presence of $0.1 \mu \mathrm{M}$ of AZD7762. Luminescence-based caspase activity assay was performed based on the manufacturer's (Promega) instructions.

\section{Western blot}

HT29 cells were exposed to TH-302, AZD7762, or combined TH-302 and AZD7762 for $2 \mathrm{~h}$ under either normoxia $\left(21 \% \mathrm{O}_{2}\right)$ or hypoxia $\left(\mathrm{N}_{2}\right)$. After removal of $\mathrm{TH}-302$, cells were continuously incubated with AZD7762 for additional $46 \mathrm{~h}$. Cell extracts were prepared and protein concentrations were determined. Proteins were detected after SDS-PAGE and Western blotting with ChemGlow detection system (ProteinSimple) using antibodies recognizing autophospho-Chk1 (S296), total Chk1, phospho-Histone H3, phosphorylated Cdc2 Y15, total Cdc2, Rad51, and actin.

\section{In vivo antitumor activity}

Female nude mice (4-6 weeks; Nu-Foxn $1^{\text {nu }}$ NU/NU, Charles River Laboratories) were tagged with microchips (Locus Technology) for identification. All animal studies were approved by the Institutional Animal Care and Use Committee at Threshold Pharmaceuticals.

HT29 cells were mixed with 50\% Matrigel and $0.2 \mathrm{ml} /$ mouse were subcutaneously implanted to the flank area of the animals. When the tumor size reached $150 \mathrm{~mm}^{3}$, mice were randomized into experimental groups.

TH-302 was dissolved in saline $(0.9 \% \mathrm{NaCl})$ at $5 \mathrm{mg} / \mathrm{ml}$ and filtered prior to animal dosing. AZD7762 was formulated in $1 \%$ DMSO, $11.3 \%$ cyclodextrin in water for injection. Maximum tolerated dose (MTD) for TH-302 in combination with AZD7762 was determined in a small number of non-tumor bearing nu/nu mice. The MTD was defined as the highest possible dose resulting in no animal deaths, less than $20 \%$ weight loss for any one animal in an experimental group, no significant changes in general clinical signs, and no abnormal gross anatomical findings after necropsy. The doses of compounds used in all studies were no higher than MTD.

Two dosing regimens of $\mathrm{TH}-302$ were employed in the study. With the TH-302 intermittent dosing regimen, TH302 was dosed intraperitoneally (ip) at $100 \mathrm{mg} / \mathrm{kg}$, twice/ wk x 2 wks. AZD7762 was dosed i.p. at either 20 or $12.5 \mathrm{mg} / \mathrm{kg}$, four times/wk $\times 2$ wks. For the combination therapy study, two different dosing sequences were investigated: (1) TH-302 was given first, and $4 \mathrm{~h}$ and $24 \mathrm{~h}$ later AZD7762 was administered (the 'TAA' sequence); and (2) AZD7762 was given first, and $4 \mathrm{~h}$ and $24 \mathrm{~h}$ later followed by TH-302 and AZD7762, respectively (the 'ATA' sequence). With the TH-302 daily dosing regimen, TH-302 was dosed ip at $50 \mathrm{mg} / \mathrm{kg}$, with a regimen of QDx $5 / \mathrm{wk} x$ 2 wks. AZD7762 $12.5 \mathrm{mg} / \mathrm{kg}$ was given under same regimen as TH-302. When the combination was scheduled, TH-302 was administered $4 \mathrm{~h}$ prior to AZD7762 (the 'TA' sequence).

Tumor growth and body weight were measured twice a week. Tumor volume was calculated as (length $\mathrm{x}$ width $\left.^{2}\right) / 2$. Drug efficacy was assessed as Tumor Growth Inhibition (TGI) and Tumor Growth Delay (TGD). TGI was defined as $(1-\Delta T / \Delta C) \times 100$, where $\Delta T / \Delta C$ presented the ratio of the change in mean tumor volume of the treated group and of the control group. TGD was calculated as the extra days for the treated tumor to reach $1000 \mathrm{~mm}^{3}$ as compared to control group $\left(\mathrm{TGD}_{1000}\right)$. Animals were culled when individual tumor size was over $2000 \mathrm{~mm}^{3}$ or individual tumor size was over $1000 \mathrm{~mm}^{3}$ if mean tumor volume exceeded $1000 \mathrm{~mm}^{3}$ in the group. Conditional survival was defined as the time that an animal reached the endpoint of a tumor size of $1000 \mathrm{~mm}^{3}$. Kaplan-Meier plots were constructed based on the percentage animals surviving in each group as a function of time. Median time (MT) is the time at which half the animals in the group had a tumor size less than $1000 \mathrm{~mm}^{3}$. The antitumor activity was evaluated as follows: $\mathrm{T} / \mathrm{C} \%=$ MT of treated group/MT of control group $\times 100$. Results were also expressed as the percentage of increased life span (ILS, T/C of treated group-100). Statistical significance between the groups was evaluated by the logrank test.

Data are expressed as the mean \pm SEM. One-way analysis of variance with Dunnett post-comparison test (GraphPad PRISM 4) or two-tail student's $t$ test were used for analysis. A $P$ level $<0.05$ was considered statistically significant.

\section{Histology and immunohistochemistry}

$300-600 \mathrm{~mm}^{3}$ HT29 xenograft tumors were used in the pharmacodynamics studies. Six animals per group were treated with vehicle, AZD7762 $25 \mathrm{mg} / \mathrm{kg}$, ip, on Day 1 and Day 2, TH-302 $150 \mathrm{mg} / \mathrm{kg}$, ip on Day 1 or the combination of AZD7762 and TH-302. In the combination treatment, two dosing sequences were used: TAA and ATA (as above). Tumors were harvested on Day 3 (which was $24 \mathrm{~h}$ after the second AZD7762 treatment), and fixed in $10 \%$ neutral buffered formalin and embedded in 
paraffin. $5 \mu \mathrm{m}$ thick paraffin sections were cut and adhered to poly-L-lysine-coated glass slides.

After deparaffinization and rehydration of the slides, antigen was retrieved. Endogenous peroxidase was quenched by Peroxidaze 1 and non-specific binding was blocked by Background Sniper (both Biocare Medical). Slides were incubated with rabbit monoclonal anti $\gamma \mathrm{H} 2 \mathrm{AX}$ (Epitomics, 1:3000), or rabbit polyclonal antiphospho Chk1 (phospho S345, Chk1-S345, Abcam, 1:25) or Caspase 3 (Cell Signaling Technology, 1:300) for $1 \mathrm{~h}$ at RT followed by secondary HRP-conjugated anti rabbit IgG (Epitomics).

\section{Image analysis}

$\gamma \mathrm{H} 2 \mathrm{AX}$, phospho-Chk1-S345 or Caspase 3 positive cells were counted at $400 \mathrm{x}$ magnification. Ten fields per section were used. The percentage of positive cells was calculated as number of $\gamma \mathrm{H} 2 \mathrm{AX}$ or Chk1-S345 positive cells/number of total cells in the field $\mathrm{x} 100 \%$. $P$ value $<0.05$ was considered significant. One-way analysis of variance with Dunnett's test (GraphPad PRISM 4) was used to compare the significance of the multiple groups. A student's t-test was used to find the significance between two groups.

\section{Results}

\section{Chk1 inhibitors sensitize human colon cancer HT29 cells to $\mathrm{TH}-302$}

As shown in Figure 1A-C and Table 1, p53-deficient HT29 cells treated with $\mathrm{TH}-302$ alone exhibited hypoxia-selective and concentration-dependent cytotoxicity (Table 1). The concentration of each Chk1 inhibitor selected for combination studies caused no significant effect on cell viability compared with vehicle-treated control cells. Combination of TH-302 and Chk1 inhibitors induced significant potentiation of the cytotoxic activity of TH-302 in HT29 cells. The combination index $(\mathrm{CI})$ determined by the ChouTalalay method was in a range of 0.9 to 0.001 (Table 2), thus ranging from demonstration of near additivity to very strong synergism.

\section{Potentiation of TH-302 activity by Chk1 inhibitors is dependent on p53-deficiency}

To explore the breadth of enhanced potency of TH-302 by the addition of Chk1 inhibitors, other human cell lines were also investigated. As shown in Table 3, the synergistic effects of TH-302 combined with Chk1 inhibitors were observed in the p53-deficient HeLa cell line but not in p53-proficient H460 or p53 heterozygous DU145 human tumor cell lines. To confirm the importance of p53 status in Chk1 inhibitor-mediated synergistic effect observed with TH-302, we employed the isogenic p53-proficient and -deficient cell line pairs, MCF10A $\mathrm{p} 53^{+/+}$and MCF10A p53 $3^{-/-}$and SW48 $\mathrm{p}^{+/+}$and SW48 $\mathrm{p} 53^{-/-}$. Parental and p53-null MCF10A and SW48 cell lines exhibited a similar sensitivity to single agent AZD7762, LY2603618 and PF477736, regardless of the p53 status. TH-302 displayed hypoxia-selective and concentration-dependent cytotoxic activity that was comparable in both p53proficient and -deficient cells. As expected, the combination treatment of TH-302 with the three Chk1 inhibitors yielded a trend of enhanced cytotoxicity profile in the cells that lack p53 compared with p53-proficient parental cells.

\section{Synergistic effect of AZD7762 and TH-302 is not}

dependent on the schedule of drug addition in HT29 cells To investigate whether the synergistic activity of the combination of AZD7762 and TH-302 is related to the sequence of drug addition, we conducted combination studies with various treatment schedules. As shown in Figure 2 and Table 4, addition of AZD7762 enhanced TH-302 activity regardless of dosing sequence or scheduling, which was evident with similar $\mathrm{IC}_{50}$ values with the different treatment schedules.

\section{AZD7762 reduces TH-302-induced cell cycle arrest}

We then investigated the effect of Chk1 inhibitors on cell cycle progression in TH-302-treated cells. As shown in Table 5, HeLa cells treated with vehicle or PF477736 alone had no appreciable changes in cell cycle distribution as determined by DNA content analysis (flow cytometry). Treatment with TH-302 alone caused an accumulation of
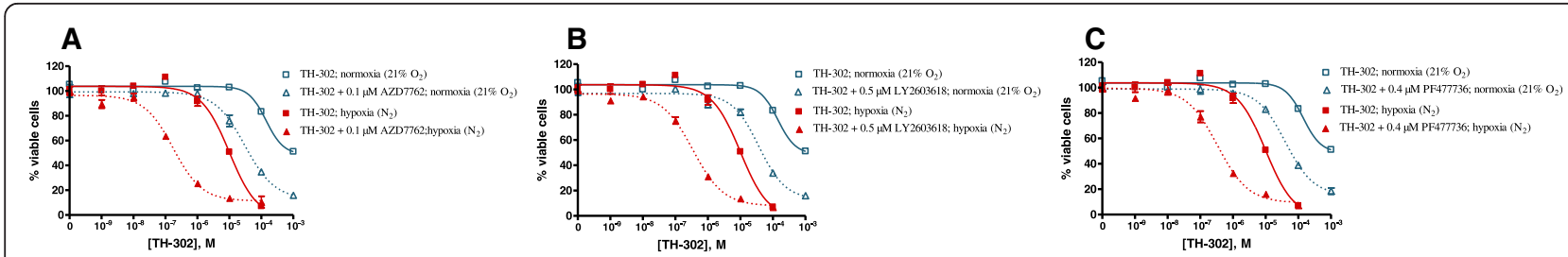

Figure 1 Enhanced TH-302 cytotoxicity by Chk1 inhibitors was observed in p53-mutant HT29 cells. HT29 cells were seeded for 24 h, and then exposed to TH-302 alone, or combined with $0.1 \mu \mathrm{M}$ of AZD7762 (A), $0.5 \mu \mathrm{M}$ LY2603618 (B), or $0.4 \mu \mathrm{M}$ PF477736 (C) for $2 \mathrm{~h}$ under either air $\left(21 \% \mathrm{O}_{2}\right)$ or hypoxia $\left(\mathrm{N}_{2}\right)$. After wash, cells were treated with the Chk1 inhibitors for an additional $70 \mathrm{~h}$ under air $\left(21 \% \mathrm{O}_{2}\right)$. The viable cells were detected using AlamarBlue and quantified with spectrophotometer. $I_{50}$ values are presented in Table 1. Combination indexes from Chou-Talalay (CalcuSyn) analyses are presented in Table 2 (air group and $\mathrm{N}_{2}$ group). The data are the representative of four independent experiments. 
Table 1 Enhanced IC $\mathrm{C}_{50 \text { s }}$ were observed in combination groups

\begin{tabular}{|c|c|c|c|}
\hline & $\begin{array}{c}\text { Normoxia }\left(21 \% \mathrm{O}_{2}\right) \\
\mathrm{IC}_{50}(\mu \mathrm{M})\end{array}$ & $\begin{array}{l}\text { Hypoxia }\left(\mathrm{N}_{2}\right) \\
\mathrm{IC}_{50}(\mu \mathrm{M})\end{array}$ & $\begin{array}{c}\text { HCR } \\
\text { Normoxia/Hypoxia } \\
\end{array}$ \\
\hline $\mathrm{TH}-302$ & 1000 & 10 & 100 \\
\hline AZD 7762 & 0.4 & N/A & N/A \\
\hline LY 2603618 & 1.7 & N/A & $\mathrm{N} / \mathrm{A}$ \\
\hline PF 477736 & 0.8 & N/A & N/A \\
\hline TH-302 and $0.1 \mu \mathrm{M}$ AZD & 39 & 0.2 & 195 \\
\hline $\mathrm{TH}-302$ and $0.5 \mu \mathrm{M} L Y$ & 46 & 0.4 & 115 \\
\hline $\mathrm{TH}-302$ and $0.4 \mu \mathrm{M}$ PF & 57 & 0.4 & 140 \\
\hline
\end{tabular}

$\mathrm{G}_{2} / \mathrm{M}$ cells. Inhibition of Chk1 by PF47736 in cells treated with TH-302 reduced TH-302-mediated $\mathrm{G}_{2} / \mathrm{M}$ arrest under both normoxia and hypoxia.

We also investigated the effect of AZD7762 in HT29 cells under hypoxic $\left(\mathrm{N}_{2}\right)$ conditions. As shown in Table 6, AZD7762 alone exhibited a minimal effect on cell cycle distribution, TH-302 alone induced concentrationdependent cell cycle arrest at $\mathrm{G}_{2} / \mathrm{M}$, and at higher concentrations, TH-302 also induced a profound S phase arrest. The combination of TH-302 with $0.1 \mu \mathrm{M}$ of AZD7762 caused a marked abrogation of TH-302induced S-phase block. In the presence of AZD7762, increasing concentration of $\mathrm{TH}-302$ up to $2 \mu \mathrm{M}$ caused no changes in the $S$-phase population compared with the concentration-dependent increase of S-phase population observed in cells treated with $\mathrm{TH}-302$ alone. Under normoxic $\left(21 \% \mathrm{O}_{2}\right)$ conditions there were no changes of cell cycle distribution in HT29 cells treated with TH-302 at tested concentrations (data not shown).
TH-302 and AZD7762 co-treatment induced DNA doublestrand breaks, but not enhanced DNA cross-linking

To assess the impact of the Chk1 inhibitor AZD7762 on DNA double-strand breaks in TH-302 treated cells, we used the single-cell gel electrophoresis-based 'comet' assay. As shown in Figure 3A and B, cells treated with (a) vehicle, (b) TH-302 under normoxia $\left(21 \% \mathrm{O}_{2}\right)$, (c) TH-302 under hypoxia $\left(0.1 \% \mathrm{O}_{2}\right)$ or (d) AZD7762, exhibited no visible tail moment (TM) with TM values ranging from 0.1-0.3. In contrast, cells co-treated with AZD7762 and TH-302 (e-h) exhibited an increased TM, indicating the induction of double-strand breaks (DSBs). Under normoxia $\left(21 \% \mathrm{O}_{2}\right)$, DSBs induced by cotreatment were $\mathrm{TH}-302$ concentration-dependent (e and f). However, under hypoxia, lower TM values were observed at higher $\mathrm{TH}-302$ concentration (h) than lower concentration ( $g$ ) due to the superimposition of DNA cross-linking. Quantification of DNA cross-linking was investigated in cells treated with bleomycin for $1 \mathrm{~h}$

Table 2 Near additivity or strong synergism was observed in combination groups

\begin{tabular}{|c|c|c|c|c|}
\hline \multirow{2}{*}{ Oxygen } & \multirow{2}{*}{ TH-302 ( $\mu \mathrm{M})$} & \multicolumn{3}{|c|}{ Combination index $(\mathrm{Cl})$} \\
\hline & & TH-302 + $0.1 \mu \mathrm{M}$ AZD & TH-302 + $0.5 \mu \mathrm{M}$ LY & TH-302 + $0.4 \mu \mathrm{M} \mathrm{PF}$ \\
\hline \multirow{7}{*}{ Normoxia $\left(21 \% \mathrm{O}_{2}\right)$} & 0.001 & 0.001 & 0.001 & 0.001 \\
\hline & 0.01 & 0.001 & 0.001 & 0.001 \\
\hline & 0.1 & 0.02 & 0.04 & 0.01 \\
\hline & 1 & 0.02 & 0.12 & 0.05 \\
\hline & 10 & 0.24 & 0.18 & 0.17 \\
\hline & 100 & 0.65 & 0.66 & 0.61 \\
\hline & 1000 & 0.84 & 0.84 & 0.81 \\
\hline \multirow{7}{*}{ Hypoxia $\left(\mathrm{N}_{2}\right)$} & 0.0001 & 0.001 & 0.001 & 0.001 \\
\hline & 0.001 & 0.001 & 0.001 & 0.001 \\
\hline & 0.01 & 0.05 & 0.05 & 0.02 \\
\hline & 0.1 & 0.36 & 0.25 & 0.23 \\
\hline & 1 & 0.74 & 0.69 & 0.67 \\
\hline & 10 & 0.86 & 0.86 & 0.84 \\
\hline & 100 & 0.9 & 0.93 & 0.93 \\
\hline
\end{tabular}


Table 3 Enhanced TH-302 cytotoxicity by Chk1 inhibitors is only observed in p53-deficient but not p53-proficient cells

\begin{tabular}{|c|c|c|c|c|c|c|c|c|c|c|c|c|c|}
\hline \multirow[b]{2}{*}{ Cell line } & \multirow[b]{2}{*}{$\begin{array}{l}\text { Cell } \\
\text { type }\end{array}$} & \multirow[b]{2}{*}{$\begin{array}{c}\text { p53 } \\
\text { status }\end{array}$} & \multirow[b]{2}{*}{$\begin{array}{l}\text { AZD } \\
7762 \\
(\mu \mathrm{M})\end{array}$} & \multirow[b]{2}{*}{$\begin{array}{c}\text { LY } \\
2603618 \\
(\mu \mathrm{M})\end{array}$} & \multirow[b]{2}{*}{$\begin{array}{c}P F \\
477736 \\
(\mu \mathrm{M})\end{array}$} & \multicolumn{4}{|c|}{ TH-302 (Normoxia; $21 \% \mathrm{O}_{2}$ ) } & \multicolumn{4}{|c|}{ TH-302 (Hypoxia; $\left.\mathrm{N}_{2}\right)$} \\
\hline & & & & & & - & $\begin{array}{l}+A Z D \\
7762 \\
(\mu \mathrm{M})\end{array}$ & $\begin{array}{c}+\mathrm{LY} \\
2603618 \\
(\mu \mathrm{M})\end{array}$ & $\begin{array}{c}+\mathrm{PF} \\
477736 \\
(\mu \mathrm{M})\end{array}$ & - & $\begin{array}{l}+A Z D \\
7762 \\
(\mu \mathrm{M}) \\
\end{array}$ & $\begin{array}{c}+\mathrm{LY} \\
2603618 \\
(\mu \mathrm{M})\end{array}$ & $\begin{array}{c}+\mathrm{PF} \\
477736 \\
(\mu \mathrm{M})\end{array}$ \\
\hline$\overline{\text { HeLa }}$ & Cervical & $\mathrm{p} 53^{-/}$ & 0.7 & 3.2 & 0.3 & $>1000$ & 95 & 90 & 200 & 100 & 0.5 & 0.4 & 2.1 \\
\hline $\mathrm{H} 460$ & NSCLC & $\mathrm{p} 53^{+/+}$ & 0.2 & 1.2 & 4.3 & 25 & 25 & 22 & 19 & 0.4 & 0.2 & 0.2 & 0.2 \\
\hline DU145 & Prostate & $\mathrm{p} 53^{+/-}$ & 0.4 & 2.3 & 0.7 & 210 & 80 & 110 & 340 & 2.7 & 1.1 & 0.9 & 1.9 \\
\hline MCF10A p $53^{+/+}$ & Breast & $\mathrm{p} 53^{+/+}$ & 0.9 & 5.7 & 1 & 110 & 44 & 61 & 75 & 0.6 & 0.4 & 0.5 & 0.6 \\
\hline MCF10A p53 & Breast & $\mathrm{p} 53^{-1}$ & 0.5 & 4.1 & 0.7 & 88 & 24 & 22 & 34 & 0.7 & 0.1 & 0.2 & 0.2 \\
\hline sW48 p53 & Colon & $\mathrm{p} 53^{+/+}$ & 0.1 & 4.1 & 0.4 & 39 & 16 & 35 & 39 & 0.09 & 0.04 & 0.07 & 0.2 \\
\hline SW48 p53 & Colon & $\mathrm{p} 53^{-/}$ & 0.1 & 0.6 & 0.1 & 110 & 19 & 22 & 27 & 1.5 & 0.2 & 0.2 & 0.2 \\
\hline
\end{tabular}

$\mathrm{IC}_{50}$ values in $\mu \mathrm{M}$. Inhibitor concentrations used for combination studies (all in $\left.\mu \mathrm{M}\right)$ : AZD7762: HeLa (0.2); H460 (0.05); DU145 (0.1); MCF10A p53 ${ }^{+/+}$and

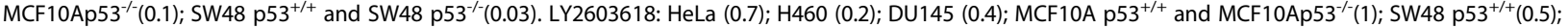

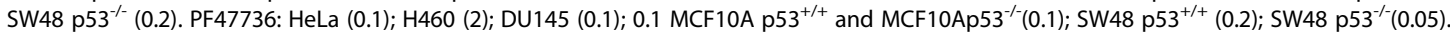

starting at the end of the drug treatment period. As shown in Figure 3C and D, $20 \mu \mathrm{M}$ of bleomycin-alone (b) produced profound DNA breaks with a TM of 29 compared with DMSO-treated cells (a). TH-302 alone under normoxia (c), under hypoxia $\left(0.1 \% \mathrm{O}_{2}\right)(\mathrm{d})$ and AZD7762 alone (e) did not produce visible TM. Consistent with previously published data [4], TH-302 treatment effectively cross-linked DNA under hypoxia $(0.1 \%$ $\mathrm{O}_{2}$; h and i) but not under normoxia $\left(21 \% \mathrm{O}_{2}\right.$; f and $\left.\mathrm{g}\right)$. The addition of AZD7762 did not change the magnitude of TH-302 cross-linking as the measured TMs (k-n) were not different. AZD7762 alone did not induce detectable DNA cross-linking at the tested concentration (j). The AZD7762 concentration tested $\left(\mathrm{IC}_{5}\right)$ is wellbelow the $\mathrm{IC}_{50}$, and thus may be too low to detect DNA damage.

\section{AZD7762 increases the TH-302 mediated DNA damage response of $\mathrm{\gamma H} 2 \mathrm{AX}$}

To investigate the effects of Chk1 inhibition on TH-302mediated DNA damage response, HT-29 cells were treated with TH-302, AZD7762, or combined TH-302 and AZD7762, and analyzed for $\gamma \mathrm{H} 2 \mathrm{AX}$ using fluorescence microscopy (Figure 4A-B). Cells treated with $0.1 \mu \mathrm{M}$ of AZD7762 under both normoxia $\left(21 \% \mathrm{O}_{2}\right)$ and hypoxia $\left(\mathrm{N}_{2}\right)$ exhibited minimal induction of $\gamma \mathrm{H} 2 \mathrm{AX}$. Consistent with previously published results [4], TH-302 induced $\gamma \mathrm{H} 2 \mathrm{AX}$ in a concentration-dependent and hypoxia-selective manner. Co-incubation with AZD7762 and $\mathrm{TH}-302$ resulted in a marked increase in $\gamma \mathrm{H} 2 \mathrm{AX}$ under both normoxia $\left(21 \% \mathrm{O}_{2}\right)$ and hypoxia $\left(\mathrm{N}_{2}\right)$. Immunoblot analysis of HT29 cells (Figure 4C) showed that variant histone $\mathrm{H} 2 \mathrm{AX}$ was only phosphorylated

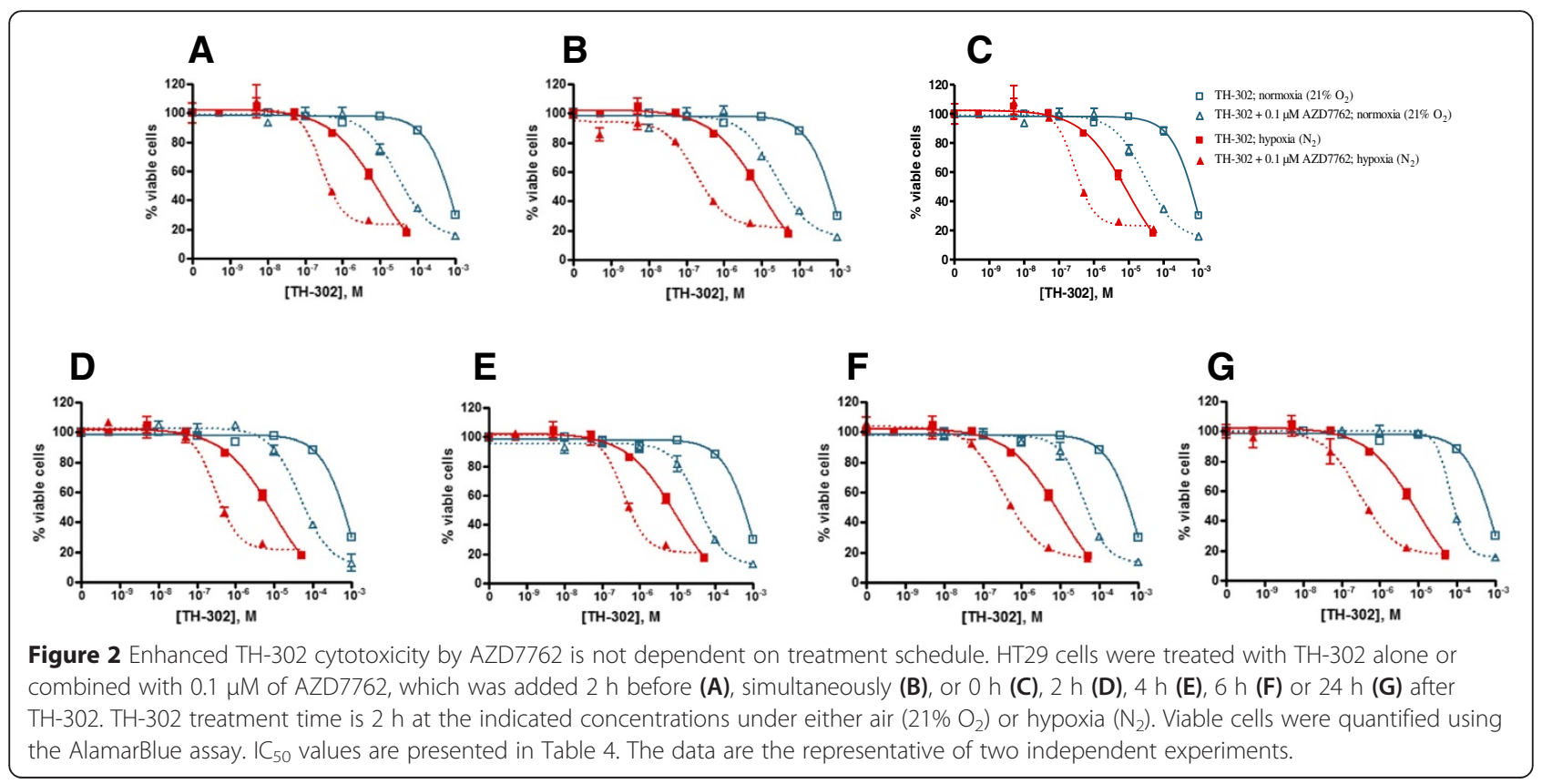


Table 4 Similar $I_{50 \text { s }}$ were observed in all combination groups regardless of treatment schedule

\begin{tabular}{|c|c|c|c|c|}
\hline & $\begin{array}{c}\text { Normoxia }\left(21 \% \mathrm{O}_{2}\right) \\
\mathrm{IC}_{50}(\mu \mathrm{M})\end{array}$ & $\begin{array}{c}\text { Potentiation } \\
\text { (fold) }\end{array}$ & $\begin{array}{c}\text { Hypoxia }\left(\mathrm{N}_{2}\right) \\
\mathrm{IC}_{50}(\mu \mathrm{M})\end{array}$ & $\begin{array}{c}\text { Potentiation } \\
\text { (fold) }\end{array}$ \\
\hline TH-302 only & 580 & & 7.4 & \\
\hline AZD7762 2 h before $\mathrm{TH}-302$ & 39 & 15 & 0.4 & 19 \\
\hline AZD7762 with TH-302 & 34 & 17 & 0.3 & 25 \\
\hline AZD7762 $0 \mathrm{~h}$ after TH-302 & 42 & 14 & 0.5 & 14 \\
\hline AZD7762 2 h post TH-302 & 61 & 10 & 0.4 & 19 \\
\hline AZD7762 4 h post TH-302 & 42 & 14 & 0.6 & 12 \\
\hline AZD7762 6 h post TH-302 & 46 & 13 & 0.6 & 12 \\
\hline AZD7762 24 h post TH-302 & 84 & 7 & 0.4 & 19 \\
\hline
\end{tabular}

significantly in cells treated with both $\mathrm{TH}-302$ and AZD7762 under either normoxia $\left(21 \% \mathrm{O}_{2}\right)$, or hypoxia $\left(\mathrm{N}_{2}\right)$ but not cells treated with vehicle, AZD7762, or TH-302 alone under either normoxia $\left(21 \% \mathrm{O}_{2}\right)$ or hypoxia $\left(\mathrm{N}_{2}\right)$.

Involvement of DNA repair in Chk1-mediated enhancement of TH-302 cytotoxicity

To investigate whether DNA repair processes play a role in the enhancement of TH-302 cytotoxicity by Chk1 inhibitors, we conducted an in vitro combination study with TH-302 and AZD7762 using paired HDR-proficient and HDR-deficient cells. Interestingly, Chk1 inhibition enhanced TH-302-mediated cytotoxicity only in HDR proficient $\mathrm{CHO}$ AA8 cells and had no significant effect on the cytotoxicity of TH-302 in HDR-deficient and cell-cycle checkpoint-proficient irs1SF and UV41 cells (Figure 5A-C). AZD7762 enhanced TH-302 cytotoxicity equally in either non-homologous end joining (NHEJ)proficient or NHEJ-deficient cells (Figure 5D-E).

\section{AZD7762 increases TH-302-mediated apoptosis}

To investigate the effect of AZD7762 on TH-302mediated apoptosis, HT-29 cells were treated with TH302, AZD7762 or both TH-302 and AZD7762 and analyzed for caspase 3/7 activity. As shown in Figure 6A, TH-302 alone did not induce caspase $3 / 7$ activity under normoxia $\left(21 \% \mathrm{O}_{2}\right)$ and only slightly increased it under hypoxia $\left(\mathrm{N}_{2}\right)$. Cells treated with AZD7762 alone showed a slight increase in caspase $3 / 7$, especially under hypoxia $\left(\mathrm{N}_{2}\right)$. However, co-treatment of TH-302 and AZD7762 greatly enhanced caspase $3 / 7$ activity. To confirm the specificity of the apoptotic endpoint, the pan-caspase inhibitor ZVAD was employed, which completely abolished caspase $3 / 7$ activity-mediated by drug treatments.

\section{Effects of TH-302 and Chk1 inhibition on Chk1 signaling pathways}

To confirm that AZD7762 inhibits Chk1, we analyzed the status of Chk1 autophosphorylation (S296 Chk1) and total Chk1. As shown in Figure 6B, TH-302 increased Chk1 autophosphorylation but did not affect total Chk1 expression. Consistent with published data [26], nontoxic concentration of $0.1 \mu \mathrm{M}$ AZD7762 inhibited Chk1 autophosphorylation both at the basal level (lane 2) and in context of enhanced Chk1 autophosphorylation after addition of TH-302 under either normoxia $\left(21 \% \mathrm{O}_{2}\right.$; lane 4$)$ or hypoxia $\left(\mathrm{N}_{2}\right.$; lane 6$)$ after $48 \mathrm{~h}$ AZD7762 treatment. Total Chk1 expression was decreased after combination treatment of $\mathrm{TH}-302$ and AZD7762 although treatment with either TH-302 or AZD7762 alone did not affect total Chk1 expression. Equal loading was confirmed by actin blot. Similar

Table 5 Chk1 inhibitors reduced TH-302-mediated HeLa cell-cycle arrest

\begin{tabular}{|c|c|c|c|c|c|c|c|}
\hline & \multirow{2}{*}{ TH-302 $\mu \mathrm{M}$} & \multicolumn{3}{|c|}{ TH-302 alone } & \multicolumn{3}{|c|}{$\mathrm{TH}-302+0.1 \mu \mathrm{M}$ PF } \\
\hline & & $\% \mathrm{G}_{0} / \mathrm{G}_{1}$ & $\% \mathrm{~S}$ & $\% \mathrm{G}_{2} / \mathrm{M}$ & $\% \mathrm{G}_{0} / \mathrm{G}_{1}$ & $\% \mathrm{~S}$ & $\% \mathrm{G}_{2} / \mathrm{M}$ \\
\hline \multirow{4}{*}{ Normoxia $\left(21 \% \mathrm{O}_{2}\right)$} & 0 & 64 & 18 & 19 & 72 & 13 & 17 \\
\hline & 12.5 & 65 & 11 & 24 & 65 & 13 & 23 \\
\hline & 25 & 61 & 12 & 27 & 71 & 10 & 19 \\
\hline & 50 & 31 & 17 & 52 & 57 & 14 & 28 \\
\hline \multirow{3}{*}{ Hypoxia $\left(\mathrm{N}_{2}\right)$} & 0.0625 & 75 & 8 & 17 & 71 & 12 & 18 \\
\hline & 0.125 & 68 & 8 & 24 & 76 & 8 & 16 \\
\hline & 0.25 & 54 & 10 & 36 & 60 & 11 & 29 \\
\hline
\end{tabular}


Table 6 Chk1 inhibitors reduced TH-302-mediated HT-29 cell-cycle arrest

\begin{tabular}{|c|c|c|c|c|c|c|}
\hline \multirow{3}{*}{$\begin{array}{l}\text { TH-302 } \\
\mu \mathrm{M}\end{array}$} & \multicolumn{6}{|c|}{ Hypoxia $\left(\mathrm{N}_{2}\right)$} \\
\hline & \multicolumn{3}{|c|}{ TH-302 } & \multicolumn{3}{|c|}{ TH-302 + $0.1 \mu \mathrm{M}$ AZD } \\
\hline & $\% \mathrm{G}_{0} / \mathrm{G}_{1}$ & $\% \mathrm{~S}$ & $\% \mathrm{G}_{2} / \mathrm{M}$ & $\% G_{0} / G_{1}$ & $\% \mathrm{~S}$ & $\% G_{2} / M$ \\
\hline 0 & 53 & 21 & 25 & 62 & 19 & 19 \\
\hline 0.125 & 36 & 17 & 47 & 45 & 17 & 37 \\
\hline 0.25 & 25 & 15 & 59 & 40 & 15 & 42 \\
\hline 0.5 & 17 & 20 & 62 & 28 & 19 & 49 \\
\hline 1 & 15 & 30 & 54 & 22 & 19 & 55 \\
\hline 2 & 14 & 51 & 33 & 24 & 18 & 53 \\
\hline
\end{tabular}

results were also observed after $24 \mathrm{~h}$ AZD7762 treatment (data not shown).

As shown in Figure 6C, HT29 cells treated with AZD7762 did not show any alteration in the expression level of phospho-Histone $\mathrm{H} 3$ compared with DMSO vehicle-treated cells. Unlike AZD7762, TH-302 under either normoxia $\left(21 \% \mathrm{O}_{2}\right)$ or hypoxia $\left(\mathrm{N}_{2}\right)$ caused a dramatic decrease of phospho-Histone H3. This effect is indicative of S-phase cell-cycle arrest, which is consistent with the increase S-phase cell population observed after TH-302 treatment (Table 6). The addition of $0.1 \mu \mathrm{M}$ AZD7762 to TH-302 treatment caused a significant induction of phospho-Histone H3 under normoxia (21\% $\mathrm{O}_{2}$ ) or hypoxia $\left(\mathrm{N}_{2}\right)$. Flow cytometry confirmed S-phase checkpoint abrogation with the majority cells having $4 \mathrm{~N}$ DNA content (Table 6).

As shown in Figure 6C, treatment of HT29 cells with TH-302 results in an increase of Cdc2-Y15 phosphorylation as a consequence of cell cycle arrest. Addition of the Chk1 inhibitor AZD7762 blocked the TH-302mediated increase of Cdc2-Y15 phosphorylation, without affecting the expression level of total Cdc2. Cells treated with AZD7762 alone did not show any changes in expression levels of phospho-cdc2 or total cdc2. Similar observations were also observed in HeLa cells (data not shown).

We next tested whether the ability of AZD7762 to sensitize HT29 cells to TH-302 correlate with an inhibition of the DNA damage response through regulation of Rad51 levels, a key protein involved in HDR. As
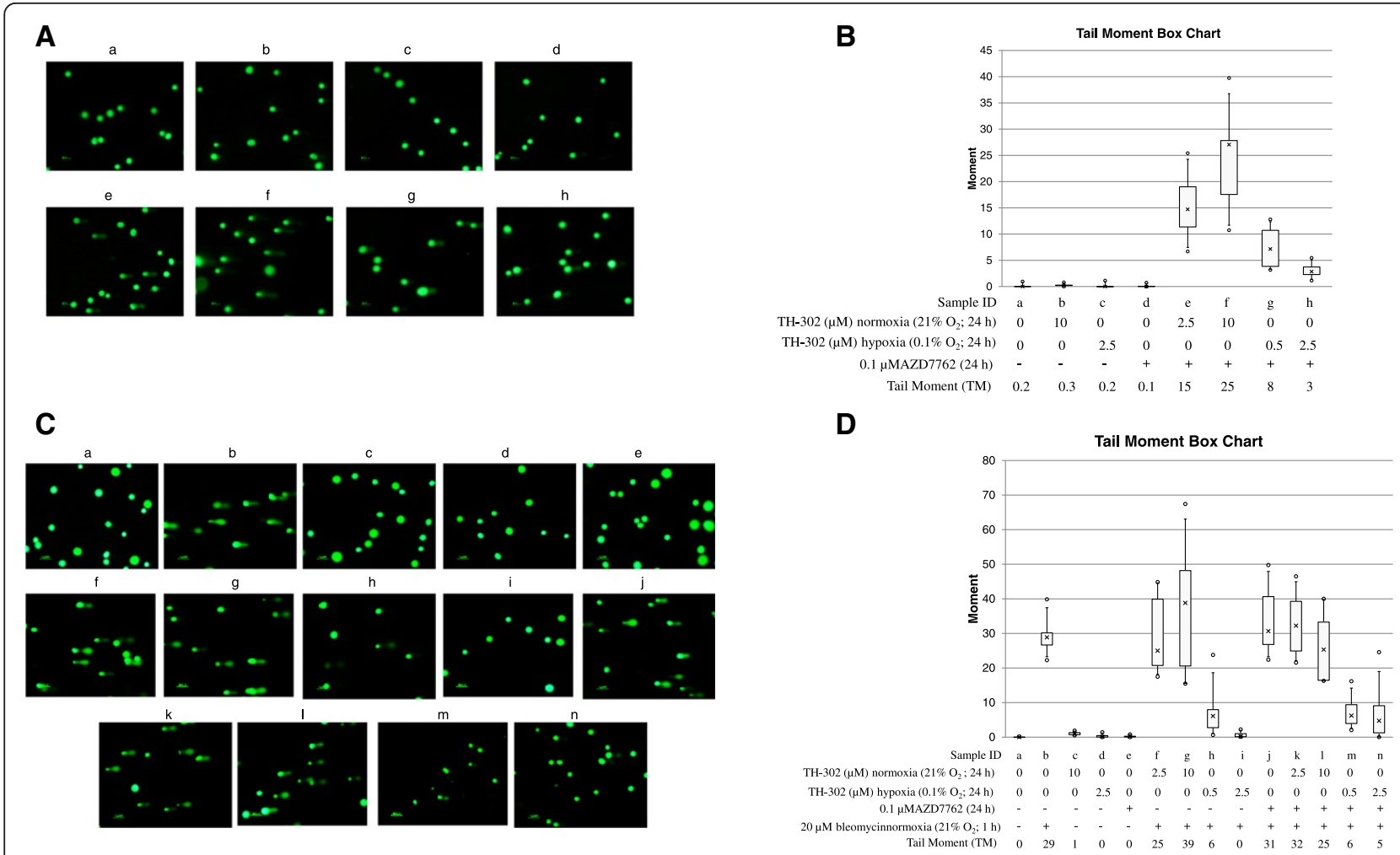

Figure 3 Co-treatment of TH-302 and AZD7762 increased tail moment but not cross-linking by Comet assay. After seeding HT-29 cells for 24 h, cells were treated at the indicated drugs and oxygen concentrations for $24 \mathrm{~h}$. To assess DNA breaks, single cell gel electrophoresis comet assay was performed (A). The length of tail moment (TM) was calculated using Comet Assay IV software (B). For cross-linking assessment, cells were treated with $20 \mu \mathrm{M}$ of bleomycin for $1 \mathrm{~h}$ at the end of the drug treatment, and then Comet assay was performed (C) and TM was calculated (D) The data are the representative of three independent experiments. 


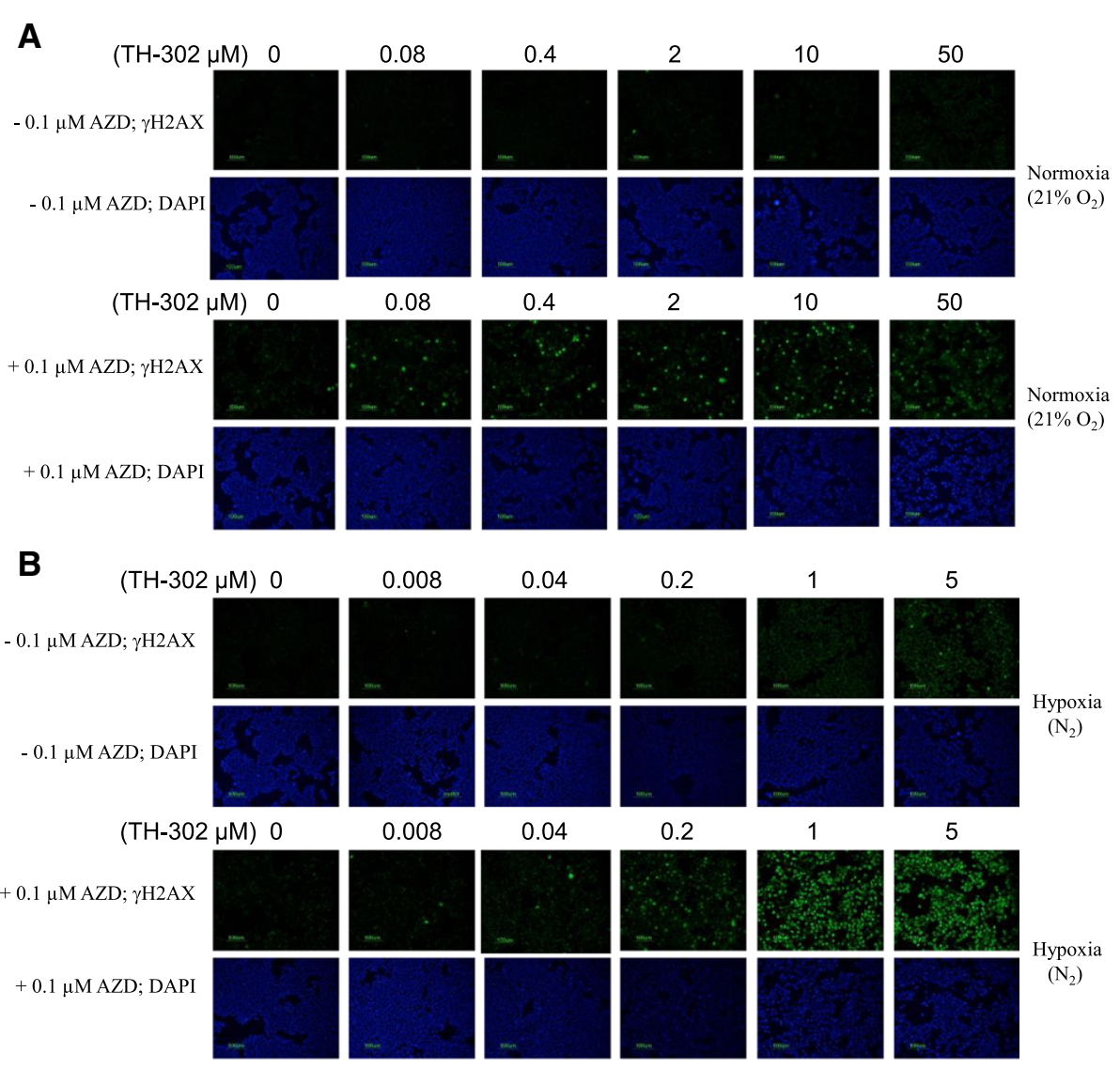

C

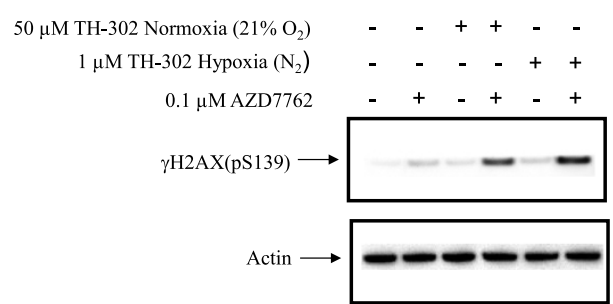

Figure 4 Enhanced $\mathrm{yH} 2 \mathrm{AX}$ signal by co-treatment of TH-302 and AZD7762. HT29 cells were treated with $\mathrm{TH}-302$ alone at the indicated concentrations, 0.1 MM AZD7762 alone, or combined treatment of TH-302 and $0.1 \mu \mathrm{M}$ AZD7762 under either air $\left(21 \% \mathrm{O}_{2}\right)$ or hypoxia $\left(\mathrm{N}_{2}\right)$ for $2 \mathrm{~h}$ and then washed. The signal of $\mathrm{YH} 2 \mathrm{AX}$ was detected by immunofluorescence microscopy (A and B) after additional $4 \mathrm{~h}$ incubation in the presence of $0.1 \mu \mathrm{M}$ AZD7762 for combination group and AZD7762 group. The blue-fluorescent nucleic acid stain DAPI was used as a nuclear counterstain. Immunoblot (C) data were generated after $22 \mathrm{~h}$ additional incubation in the presence of $0.1 \mu \mathrm{M}$ AZD7762 for combination group and AZD7762 group. The data are the representative of two independent experiments.

shown in Figure 6C, TH-302 alone increased the expression level of Rad51 by Western blot analysis while AZD7762 alone did not significantly alter the expression level of Rad51. The addition of AZD7762 significantly attenuated the expression of Rad51 in cells co-treated with TH-302. Thus, the expression changes of histone H3, Cdc2-Y15 and Rad51 suggest that the combination increases the DNA damage response, consistent with the increased DNA damage directly measured with the single cell gel electrophoresis comet assay.

AZD7762 potentiates the anti-tumor efficacy of TH-302 in the HT-29 xenograft model

$20 \mathrm{mg} / \mathrm{kg}$ AZD7762 in combination with $100 \mathrm{mg} / \mathrm{kg} \mathrm{TH}-$ 302 reached MTD. AZD7762 $20 \mathrm{mg} / \mathrm{kg}$ and $12.5 \mathrm{mg} / \mathrm{kg}$ were used. Two dosing sequences of treatment were 


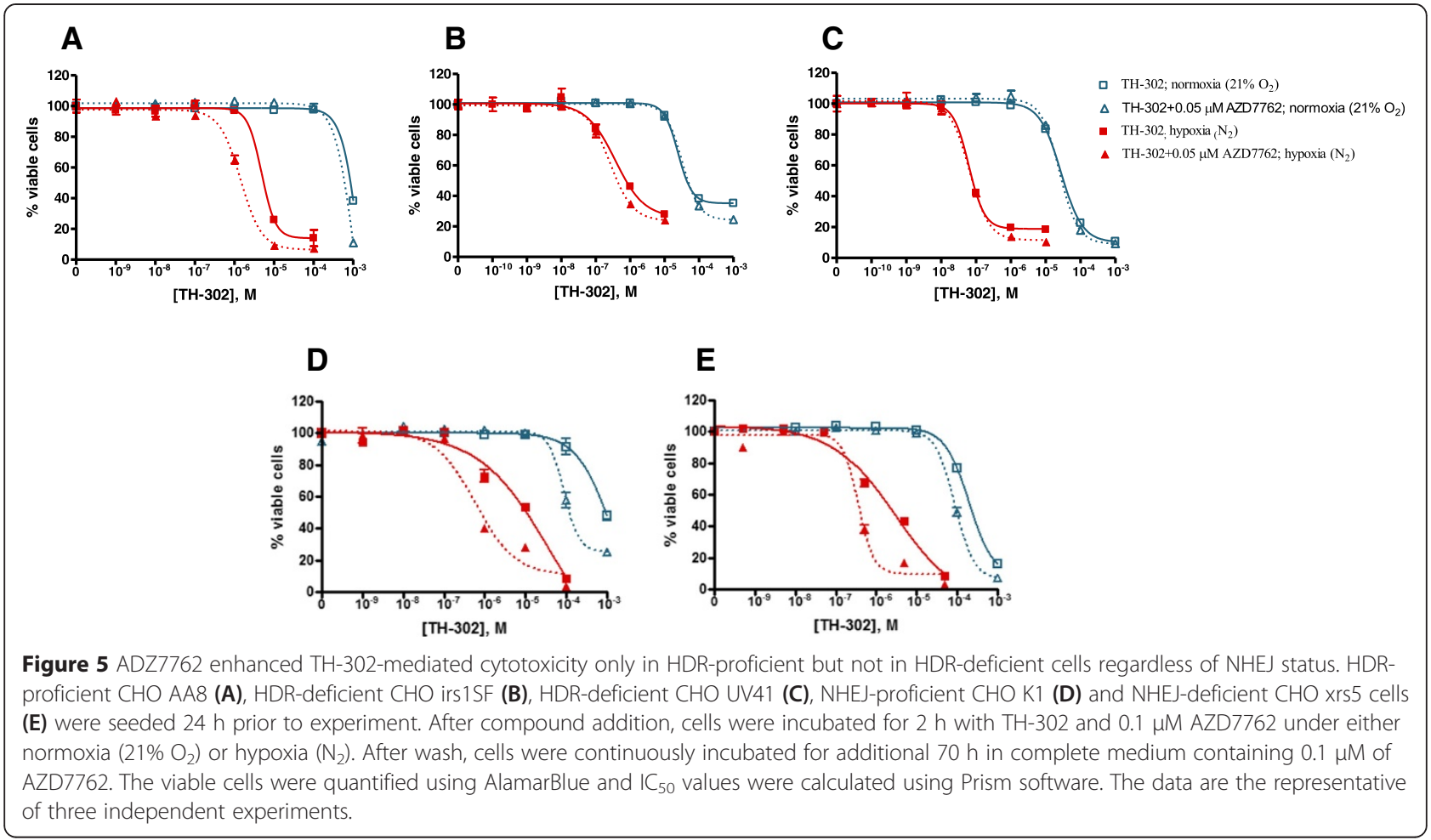

employed in the combination groups (Figure 7A). In the high dose of AZD7762 $20 \mathrm{mg} / \mathrm{kg}$ groups, TH-302 or AZD7762 alone exhibited antitumor activity, however, the tumor inhibition observed with the combination of $\mathrm{TH}$ 302 and AZD7762 was significantly increased in both dosing sequences tested $(\mathrm{p}<0.05$, Figure $7 \mathrm{~B}$ and $\mathrm{C}$, Table 7 ). There was no statistically significant difference in the tumor growth inhibition observed between the two dosing sequences, but there was a clear trend suggesting that the ATA sequence yielded greater antitumor activity compared with TAA, with TGI increased by $19 \%$. The TGD to $1000 \mathrm{~mm}^{3}$ was doubled in the ATA sequence group compared with the TAA group. In addition, using conditional survival as a read out, the ILS was 53\% in ATA group vs. $22 \%$ in TAA group.

Toxicity of the different regimens was assessed by body weight changes. As shown in the Figure 7D, TH302 or AZD7762 alone did not induce body weight loss. When the two drugs were combined, maximal body weight loss in the ATA sequence group was only $1.3 \%$ compared with $5.8 \%$ in the TAA group. Taken together with antitumor activity, the results indicate that ATA is a more optimal dosing sequence with a more favorable therapeutic index.

Lower dose of AZD7762 $12.5 \mathrm{mg} / \mathrm{kg}$ in combination with TH-302 also showed an enhanced antitumor activity (Figure $7 \mathrm{E}$ and $\mathrm{F}$ ). Here the two dosing sequences yielded similar antitumor activity and no dosing sequence superiority was observed between ATA and TAA. In the Kaplan-Meier plot, MT in the ATA group was 45 days compared to 52 days in the TAA group, but there was no significant difference between the two groups. Consistent with the higher dose of AZD7762 experiment, the TAA sequence group experienced more body weight loss than the ATA sequence group (Figure 7G).

In the TH-302 daily dosing regimen study, a similar additive effect was observed in the combination groups, and there was almost no body weight loss observed throughout the study (Figure 7H-K, Table 7).

\section{Pharmacodynamic biomarkers responsive to AZD7762 and TH-302 in HT29 xenografts}

The treatment schedule is presented in Figure 8A. In the vehicle treated HT29 xenograft tumors, few $\gamma \mathrm{H} 2 \mathrm{AX}$ positive cells were present (Figure 8B). After AZD7762 or TH-302 treatment, there is a significant increase of $\gamma \mathrm{H} 2 \mathrm{AX}$ positive cells $(8.2 \pm 0.5 \%$ and $13.6 \pm 0.5 \%$ in the AZD7762 and TH-302 groups, respectively, compared with $3.1 \pm 0.5 \%$ in vehicle, $\mathrm{p}<0.05$ ). In the combination groups, the percentage of $\gamma \mathrm{H} 2 \mathrm{AX}$ positive cells observed was significantly higher than either monotherapy group (Figure $8 \mathrm{C}$ ), and $\gamma \mathrm{H} 2 \mathrm{AX}$ positive cells after ATA sequence treatment was significantly higher than observed in the TAA sequence group. $\gamma \mathrm{H} 2 \mathrm{AX}$ positive cells in vehicle, AZD7762, and combination groups exhibited pan- 
A

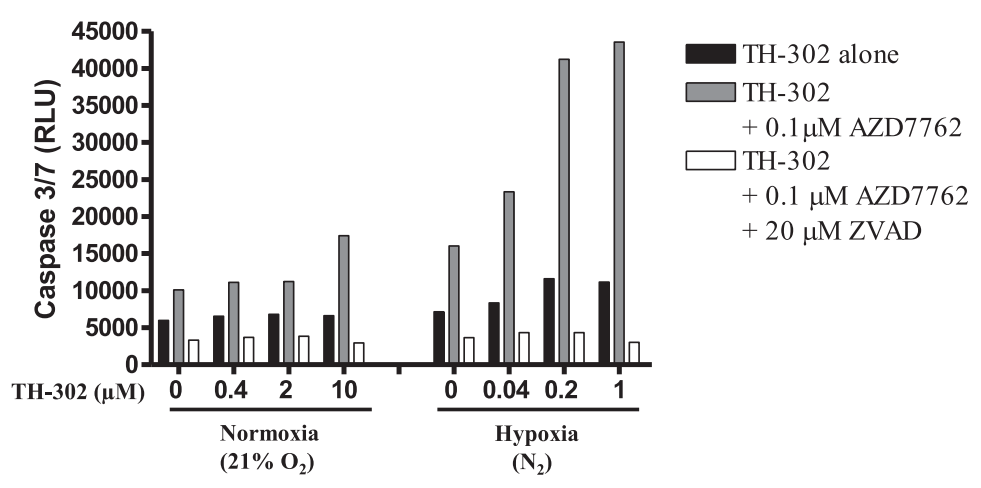

B

$1 \mu \mathrm{M}$ TH-302 Hypoxia $\left(\mathrm{N}_{2}\right) \quad-\quad-\quad-\quad+\quad+$

$0.1 \mu \mathrm{M}$ AZD7762 $\quad-\quad+\quad-\quad+\quad-\quad+$
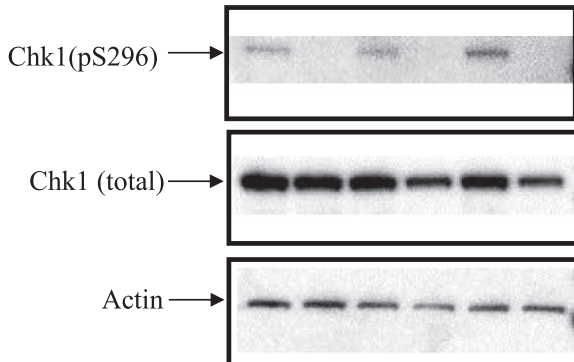

C

$50 \mu \mathrm{M}$ TH-302 Normoxia $\left(21 \% \mathrm{O}_{2}\right) \quad-\quad-\quad+\quad+\quad-$

$1 \mu \mathrm{M}$ TH-302 Hypoxia $\left(\mathrm{N}_{2}\right)$ - $\quad-\quad-\quad+\quad+$

$0.1 \mu \mathrm{M}$ AZD7762 $\quad-\quad+\quad-\quad+\quad-\quad+$

P-Histone $\mathrm{H} 3 \longrightarrow \longrightarrow-$
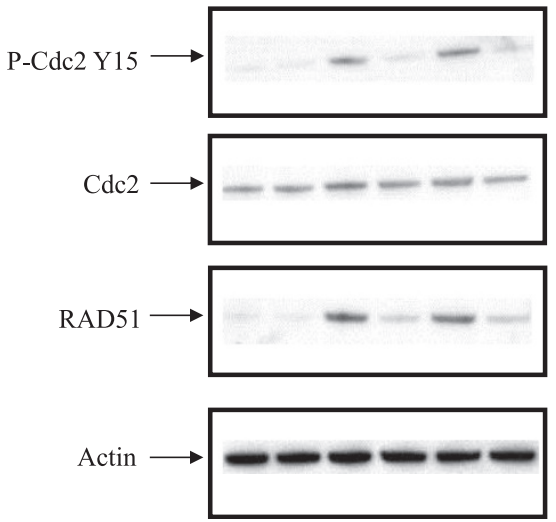

Figure 6 (See legend on next page.) 
(See figure on previous page.)

Figure 6 (A) AZD7762 enhanced apoptosis in cells co-treated with TH-302. HT29 cells were exposed to TH-302 at the indicated concentrations and $0.1 \mu \mathrm{M}$ of AZD7762 for $2 \mathrm{~h}$ under either normoxia $\left(21 \% \mathrm{O}_{2}\right)$ or hypoxia $\left(\mathrm{N}_{2}\right)$. After wash, cells were continuously cultured for additional $46 \mathrm{~h}$ in the presence of $0.1 \mu \mathrm{M}$ AZD7762. Caspase 3/7 activity was detected using luminescence-based caspase activity assay kit. The specificity of caspase 3/7 activity was confirmed by including pan-caspase inhibitor ZVAD. (B) AZD7762 inhibited Chk1 autophosphorylation. HT29 cells were treated with TH-302, AZD7762, or combination of TH-302 and AZD7762 for 2 h, washed, and AZD7762 added back and incubated for an additional 46 h. Cell lysates were harvested and immunoblotted with antibodies against Chk1 autophosphorylation (S296) and total Chk1. Equal loading was confirmed by actin blot. (C) TH-302 AZD7762 co-treatment abrogated cell cycle arrest biomarkers and decreased Rad51 expression. Cells were treated as described in Figure 6B, and then immunoblotted with antibodies against cell-cycle biomarkers phospho-histone H3, phospho-Cdc2 Y15, total Cdc2 and Rad51. Equal loading was confirmed by actin blot. The blot data are the representative of two independent experiments.

nuclear staining, while in the TH-302 treated group, foci of $\gamma \mathrm{H} 2 \mathrm{AX}$ formation was more commonly observed. Similar results were observed on Caspase 3 immunostaining (Figure 8D), a marker for apoptosis. To confirm Chk1 inhibition by AZD7762 in vivo, we analyzed phospho-Chk1-S345 positivity. The number of phosphoChk1-S345 positive cells increased in response to AZD7762 treatment, but not to $\mathrm{TH}-302$ treatment; and a further increase in the combination treated animals with the greatest increase in the ATA group (Figure 8E).

\section{Discussion}

Both the in vitro and in vivo preclinical results described here demonstrate the potentiation of $\mathrm{TH}-302$ efficacy by the addition of Chk1 inhibitors in the context of p53 deficiency. Our findings suggest that TH-302 cytotoxicity may be enhanced through at least two Chk1-dependent mechanisms. The first mechanism is abrogation of DNA damage-dependent cell cycle arrest, which is supported by the finding that Chk1 inhibition sensitizes the $\mathrm{p} 53^{-/-}$ cells but not the $\mathrm{p} 53^{+/+}$cells to $\mathrm{TH}-302$. Substantial literature supports that Chk1 inhibitors selectively sensitize tumor cells with p53 deficiency to DNA damaging agents [24-28]. More than 50\% of human tumors have mutations in p53 [31]. Cells deficient in p53 cannot undergo p53-dependent apoptosis and are resistant to drugs that induce a p53-dependent apoptosis. Such resistance has been reported in many p53 null or mutated human cancer cell lines as well as in clinical samples [32]. Indeed inhibition of Chk1 in tumor cells, either by siRNA knockdown of Chk1 protein expression [19], or by small molecules inhibiting its kinase activity, demonstrated its role in the potentiation of the cytotoxic activity of DNA damaging agents $[18,19]$ This model is also supported by the findings that Chk1 inhibition preferentially sensitizes p53 deficient human cancer cells, but not p53 functional cells to gemcitabine, radiation and 5fluorouracil $[29,33,34]$.

The second mechanism of enhanced TH-302 cytotoxicity by Chk1 inhibitor is related to HDR inhibition. Based on our previously published study, HDR plays the key role in the response and repair of $\mathrm{TH}$-302-induced
DNA cross-links [4]. Enhanced TH-302 activity was also observed in Rad51 knockout cell lines and in triplenegative breast cancer cell lines exhibiting an HDRdeficient (BRCA-like) phenotype [35,36]. It has been proposed that Chk1 is required for HDR [17], which normally occurs in the $\mathrm{S}$ and $\mathrm{G}_{2}$ phase [37]. p53mutated cells lack a $G_{1}$ checkpoint, and thus they may be more dependent on HDR [26]. Thus, it would be anticipated that Chk1 inhibition would predominantly affect HDR in p53-mutated cells [17]. The requirement for HDR inhibition in TH-302 sensitization by Chk1 inhibitors is shown by a lack of TH-302 sensitization by Chk1 inhibition in HDR-deficient cells. However NHEJproficient and -deficient cells exhibited a similar Chk1 inhibitor-involved sensitization to TH-302. Furthermore, our findings demonstrate that Chk1 inhibitors can downregulate $\mathrm{TH}$-302-induced overexpression of $\operatorname{Rad} 51$, and subsequently restore cell sensitivity to TH-302. The current findings suggest that Chk1 inhibition may offer considerable benefit to TH-302 in Rad51-overexpressing tumors. Pancreatic ductal adenocarcinoma is a cancer type where overexpression of Rad51 has been described [38]. Chk1 is involved in HDR by directly phosphorylating Rad51 and in the recruiting of Rad51 to sites of DNA damage $[17,39,40]$. It has also been reported that a Chk1 inhibitor reduces Rad51-mediated HDR [17]. To determine whether Rad51 is involved in the enhancement of TH-302 by AZD7762, we examined the Rad51 expression in cells exposed to TH-302, AZD7762, or combined TH302 and AZD7762. Rad51 levels increased in cells treated with TH-302. Rad51 protein levels were not affected by AZD7762. However, AZD7762 abolished Rad51 upregulation mediated by TH-302. Although both inhibition of cell cycle arrest and HDR are associated with TH-302 sensitization by Chk1 inhibitors, the relative importance of these effects remains to be determined.

Upon DNA damage, Chks are activated and promote cell cycle arrest at $G_{2}$ phase. $G_{2}$ arrest correlates with an increase of Cdc2 inhibitory phosphorylation at its T14 and Y15 sites. Flow cytometry data confirmed that Chk1 inhibitors abrogate $\mathrm{TH}$-302-induced $\mathrm{G}_{2}$ arrest in HeLa cells and S arrest in HT 29 cells. Consistent with flow 


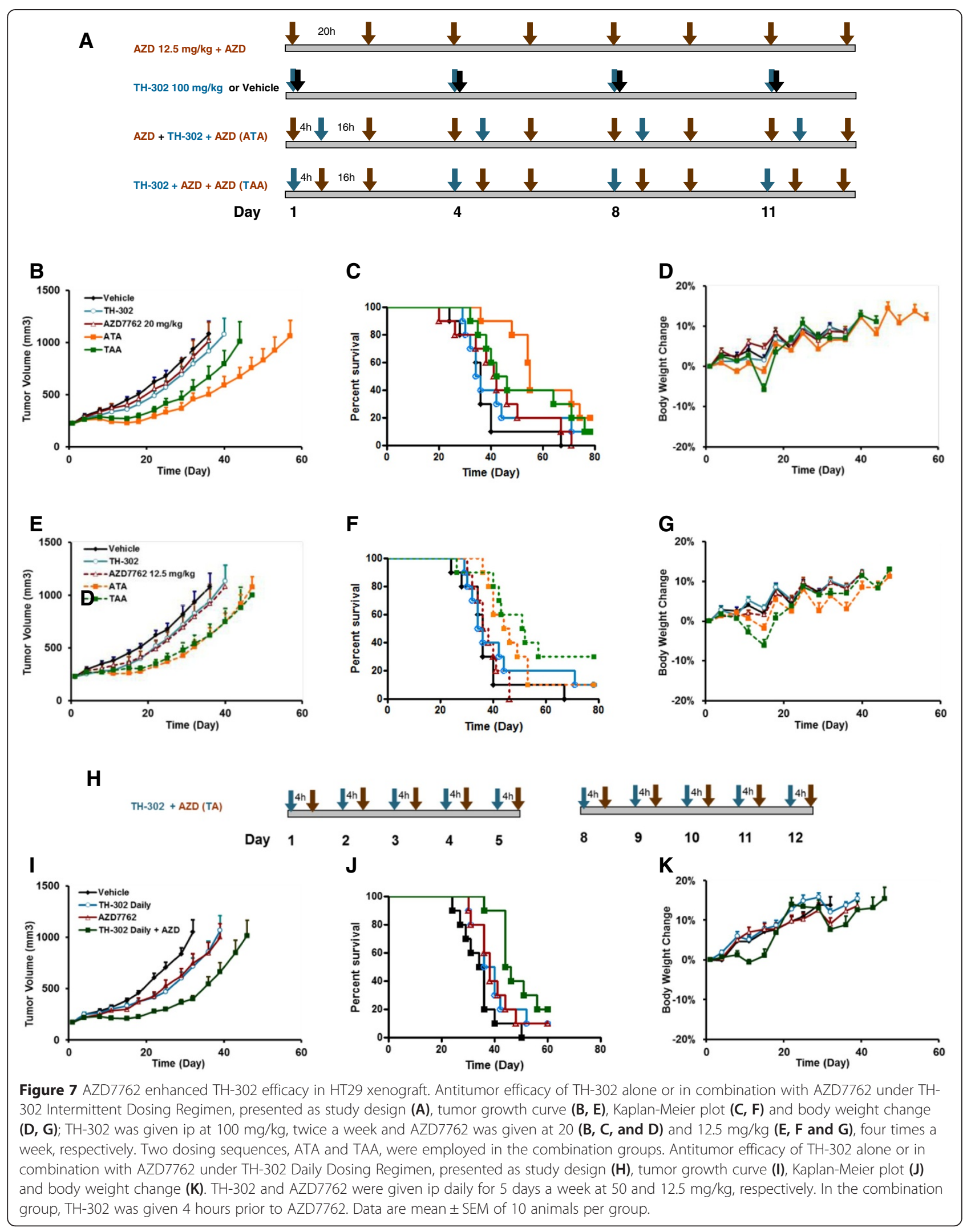


Table 7 Antitumor activity and body weight change of TH-302 in combination with AZD7762 in the HT29 xenograft model

\begin{tabular}{|c|c|c|c|c|c|c|c|c|c|c|c|c|c|c|c|}
\hline & \multicolumn{5}{|c|}{$\begin{array}{c}\text { TH-302 Intermittent Regimen } \\
\text { TH-302 } 100 \text { mg/kg, AZD } 20 \text { mg/kg, }\end{array}$} & \multicolumn{5}{|c|}{$\begin{array}{c}\text { TH-302 Intermittent Regimen } \\
\text { TH-302 } 100 \mathrm{mg} / \mathrm{kg} \text {, AZD } 12.5 \mathrm{mg} / \mathrm{kg} \text {, }\end{array}$} & \multicolumn{5}{|c|}{$\begin{array}{c}\text { TH-302 Daily Regimen } \\
\text { TH-302 } 50 \mathrm{mg} / \mathrm{kg} \text {, AZD } 12.5 \mathrm{mg} / \mathrm{kg} \text {, }\end{array}$} \\
\hline & $\begin{array}{l}\text { TGI } \\
(\%)\end{array}$ & $\begin{array}{l}\mathrm{TGD}_{1000} \\
\text { (days) }\end{array}$ & $\begin{array}{c}\text { MT } \\
\text { (days) }\end{array}$ & $\begin{array}{l}\text { ILS } \\
(\%)\end{array}$ & $\begin{array}{c}\text { MBL } \\
(\%)\end{array}$ & $\begin{array}{l}\text { TGI } \\
(\%)\end{array}$ & $\begin{array}{l}\mathrm{TGD}_{1000} \\
\text { (days) }\end{array}$ & $\begin{array}{c}\text { MBL } \\
(\%)\end{array}$ & $\begin{array}{c}\text { MT } \\
\text { (day) }\end{array}$ & $\begin{array}{l}\text { ILS } \\
(\%)\end{array}$ & $\begin{array}{l}\text { TGI } \\
(\%)\end{array}$ & $\begin{array}{l}\mathrm{TGD}_{1000} \\
\text { (days) }\end{array}$ & $\begin{array}{c}\text { MBL } \\
(\%)\end{array}$ & $\begin{array}{c}\text { MT } \\
\text { (days) }\end{array}$ & $\begin{array}{l}\text { ILS } \\
\text { (\%) }\end{array}$ \\
\hline Vehicle & & & 36 & & 0 & & & 0 & 36 & & & & 0.1 & 35 & \\
\hline AZD7762 & 7.7 & 2 & 42 & 15 & 0 & 16 & 3 & 0 & 37 & 28 & 34 & 5 & 0 & 38 & 8.6 \\
\hline TH-302 & 19 & 4 & 35 & -2.8 & 0 & 19 & 4 & 0 & 35 & -2.8 & 38 & 7 & 0 & 38 & 8.6 \\
\hline ATA & $67^{*, a, b}$ & 21 & $55^{*, a}$ & 53 & 1.3 & $54^{* a, b}$ & 11 & 1.8 & $45^{*, a}$ & 25 & - & - & - & - & - \\
\hline TAA & $48^{*, a, b}$ & 10 & $44^{*}$ & 22 & 5.8 & $54^{* a, b}$ & 13 & 6.1 & 52 & 43 & - & - & - & - & - \\
\hline TA & - & - & - & - & - & - & - & - & - & - & $74^{* a, b}$ & 16 & 0.7 & $45^{*}$ & 29 \\
\hline
\end{tabular}

TGI, tumor growth inhibition.

TGD1000, tumor growth delay to $1000 \mathrm{~mm}^{3}$.

MBL, maximal body weight loss due to drug treatment as compared with the first day of treatment.

MT: Median Time to reach the size of $1000 \mathrm{~mm}^{3}$.

ILS: Increased Life Span.

* $\mathrm{p}<0.05$ vs. vehicle group.

a $<0.05$ vs. AZD7762 group.

${ }^{b} p<0.05$ vs. TH-302 group.

cytometry data, induction of pY15 Cdc2 was observed following TH-302 treatment in vitro and this signal was abolished and phosphorylation of histone $\mathrm{H} 3$ was enhanced in the co-treatment group of $\mathrm{TH}-302$ with Chk1 inhibitors.

Co-treatment of TH-302 and AZD7762 caused a dramatic increase in DNA breaks as measured by $\gamma \mathrm{H} 2 \mathrm{AX}$ staining and directly assessed with the single cell electrophoresis comet assay. Co-treatment of TH-302 and AZD7762 under normoxia produced a concentrationdependent and a greater tail moment compared to under hypoxia. This observation is consistent with a high level of DNA cross-linking of the broken DNA fragments under hypoxia, leading to slower migration of larger molecular weight fragments.

Chk1 plays a key role in protecting cells from apoptosis in response to many types of DNA damage [21]. Down-regulation of Chk1 has been shown to selectively induce apoptosis in cancer cells [41]. Our data showed that co-treatment of TH-302 and AZD7762 induced apoptosis although neither TH-302 nor AZD7762 alone induced a high level of apoptosis.

Preclinical studies have shown that AZD7762 potentiates DNA and replication-targeted therapies, including cisplatin, gemcitabine, irinotecan, and paclitaxel $[24,29,42-44]$. Similarly, the antitumor efficacy and levels of the corresponding biomarkers, $\gamma \mathrm{H} 2 \mathrm{AX}$ and caspase-3, from the combination of $\mathrm{TH}-302$ and AZD7762 was significantly increased in the p53 mutant HT29 human tumor xenograft model. $\gamma \mathrm{H} 2 \mathrm{AX}$ was induced by AZD7762 or TH-302 alone and to a greater level when AZD7762 and TH-302 were combined. The induction of $\gamma \mathrm{H} 2 \mathrm{AX}$ by AZD7762 alone was consistent with the findings of Mitchell et al. [24], and which may be the result of replication stress [18,45]. Of note, the higher dose AZD7762 (20 mg/kg) group showed a sequence-dependent superior efficacy when combined with $\mathrm{TH}-302$, which was consistent with the biomarker findings showing enhanced downstream PD effects with the same sequence. AZD7762 given first, followed by TH-302, and then followed by another dose of AZD7762 might be an optimal dosing sequence for future preclinical and clinical studies. Taking together the in vivo efficacy profile and pharmacodynamic results, the HT29 xenograft data reported here support the hypothesis for a selective enhancement of TH-302 antitumor activity by the coadministration of a Chk1 inhibitor. As TH-302 predominantly and selectively targets hypoxic cells [4,6] even though all the tumor cells are chemosensitized by AZD7762, a triplet combination of AZD7762, TH-302, and a chemotherapeutic targeting the normoxic compartment may lead to an even superior efficacy profile [5]. A similar therapeutic strategy can also be applied with hypoxia-activated Chk1 inhibitors $[15,16]$ in combination with conventional cancer drugs targeting normoxic cells.

The results presented here support the following model for enhanced TH-302 activity by Chk1 inhibition. Hypoxia-activated TH-302 fragments in a one-electron reductase-dependent and hypoxia-selective manner, and releases the bis-alkylating effector Br-IPM, causing DNA cross-linking. Upon the recognition of the DNA damage by the DNA damage response (DDR), the variant histone 


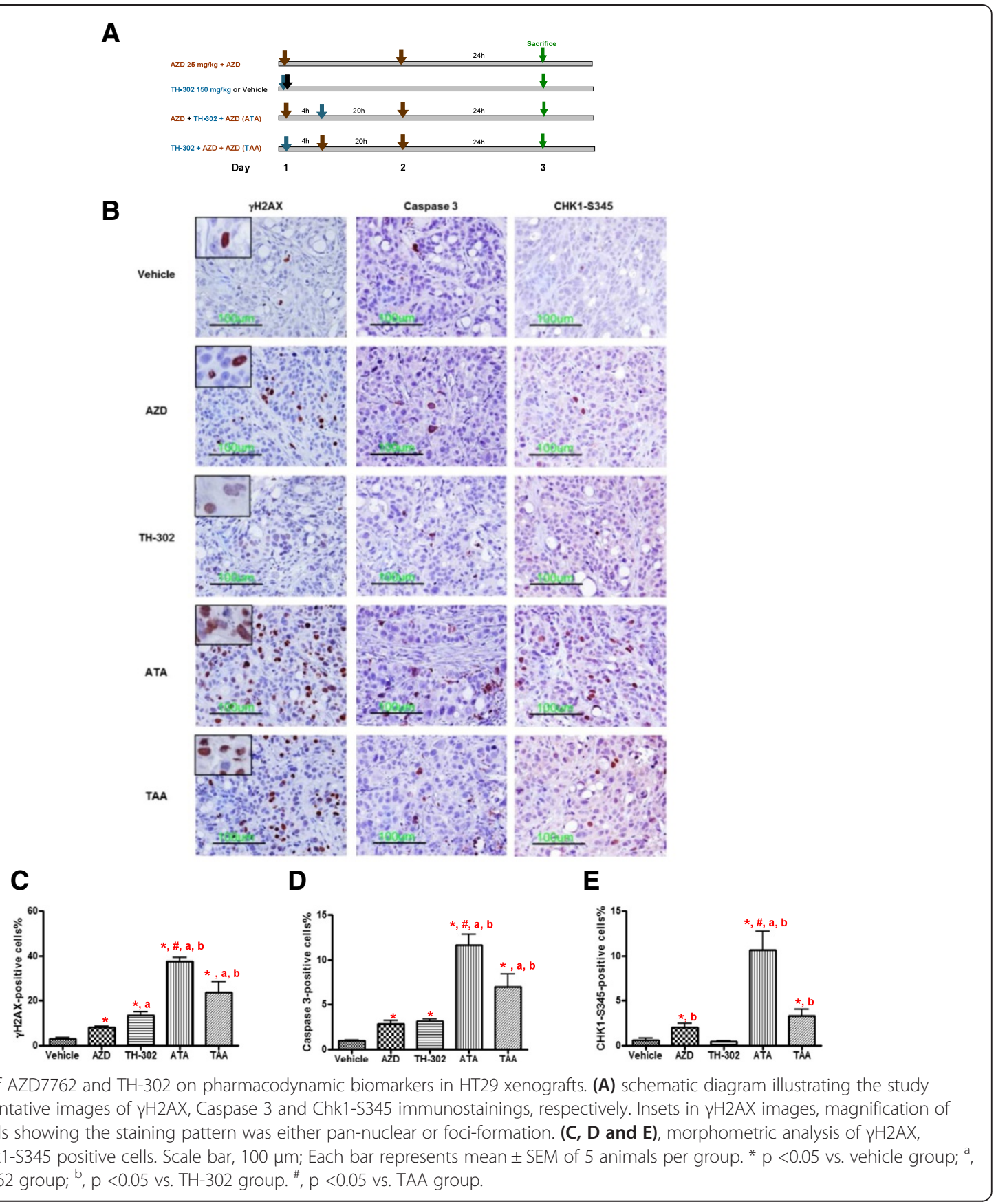

$\mathrm{H} 2 \mathrm{AX}$ is phosphorylated; yielding $\gamma \mathrm{H} 2 \mathrm{AX}$, and Chk1 is activated. Chk1 phosphorylates Cdc2 at Y15, blocking phosphorylation of histone $\mathrm{H} 3$ and arresting the cell cycle at $G_{2} / M$ and $S$ phase as well as allowing cells to undergo HDR-mediated DNA repair. When Chk1 is inhibited by a small molecule inhibitor, for example AZD7762, Chk1 inhibition triggers phosphorylation of histone $\mathrm{H} 3$, reduces $\mathrm{Cdc} 2$ phosphorylation, and leads to abrogation of cell cycle arrest. This allows arrested cells to progress directly into mitosis in cells co-treated with TH-302. Furthermore, Chk1 inhibition downregulated
TH-302-induced upregulation of DNA repair protein Rad51, a key component of the specific DNA repair pathway. TH-302 treatment in the context of Chk1 inhibition activates caspases and induces apoptosis.

\section{Conclusions}

In conclusion, we have demonstrated that $\mathrm{TH}-302$ in vitro and in vivo activity were greatly enhanced by Chk1 inhibition. The data presented here could have relevance to the clinical use of TH-302 by combining with Chk1 inhibitors for the treatment of p53-deficient cancers. 


\section{Abbreviations}

Br-IPM: Bromo-isophosphoramide mustard; Chk: Check-point kinase DSBs: Double-strand breaks; HDR: Homology-directed repair; NHEJ: Non-homologous end joining; MT: Median time; TGD: Tumor growth delay; TGI: Tumor growth inhibition; TM: Tail moment; ZVAD: Benzyloxycarbonyl-ValAla-D; DDR: DNA damage response; PD: Pharmacodynamic

\section{Competing interests}

The authors declare that they have no competing interests. All authors are employees of Threshold Pharmaceuticals.

\section{Authors' contributions}

FM, DB, JDS, QL, DA and YW performed research and conducted data analysis. $\mathrm{CPH}$ and MDM provided final approval of the manuscript. FM and $\mathrm{CPH}$ are accountable for all aspects of the work. All authors read and approved the final manuscript.

\section{Acknowledgments}

We would like to acknowledge Threshold Pharmaceuticals and Merck KGaA's financial support of this study.

\section{Received: 18 December 2014 Accepted: 28 April 2015 Published online: 21 May 2015}

\section{References}

1. Brown JM, Wilson WR. Exploiting tumour hypoxia in cancer treatment. Nat Rev Cancer. 2004;4(6):437-47.

2. Wilson WR, Hay MP. Targeting hypoxia in cancer therapy. Nat Rev Cancer. 2011;11(6):393-410

3. Duan JX, Jiao H, Kaizerman J, Stanton T, Evans JW, Lan L, et al. Potent and highly selective hypoxia-activated achiral phosphoramidate mustards as anticancer drugs. J Med Chem. 2008;51(8):2412-20.

4. Meng F, Evans JW, Bhupathi D, Banica M, Lan L, Lorente G, et al. Molecular and cellular pharmacology of the hypoxia-activated prodrug TH-302. Mol Cancer Ther. 2012;11(3):740-51.

5. Liu Q, Sun JD, Wang J, Ahluwalia D, Baker AF, Cranmer LD, et al. TH-302, a hypoxia-activated prodrug with broad in vivo preclinical combination therapy efficacy: optimization of dosing regimens and schedules. Cancer Chemother Pharmacol. 2012;69(6):1487-98.

6. Sun JD, Liu Q, Wang J, Ahluwalia D, Ferraro D, Wang Y, et al. Selective tumor hypoxia targeting by hypoxia-activated prodrug TH-302 inhibits tumor growth in preclinical models of cancer. Clin Cancer Res. 2012;18(3):758-70.

7. Portwood S, Lal D, Hsu YC, Vargas R, Johnson MK, Wetzler M, et al. Activity of the hypoxia-activated prodrug, $\mathrm{TH}-302$, in preclinical human acute myeloid leukemia models. Clin Cancer Res. 2013;19(23):6506-19.

8. Ganjoo KN, Cranmer LD, Butrynski JE, Rushing D, Adkins D, Okuno SH, et al. A phase I study of the safety and pharmacokinetics of the hypoxia-activated prodrug TH-302 in combination with doxorubicin in patients with advanced soft tissue sarcoma. Oncology. 2011:80(1-2):50-6.

9. Weiss GJ, Infante JR, Chiorean EG, Borad MJ, Bendell JC, Molina JR, et al. Phase 1 study of the safety, tolerability, and pharmacokinetics of TH-302, a hypoxia-activated prodrug, in patients with advanced solid malignancies. Clin Cancer Res. 2011;17(9):2997-3004.

10. Chawla SP, Cranmer LD, Van Tine BA, Reed DR, Okuno SH, Butrynski JE, et al. Phase II study of the safety and antitumor activity of the hypoxia-activated prodrug TH-302 in combination with doxorubicin in patients with advanced soft tissue sarcoma. J Clin Oncol. 2014;32(29):3299-306.

11. Borad MJ, Reddy SG, Bahary N, Uronis HE, Sigal D, Cohn AL, et al. Randomized phase II trial of gemcitabine plus TH-302 versus gemcitabine in patients with advanced pancreatic cancer. J Clin Oncol. 2014;33(13):1475-81.

12. Ma CX, Janetka JW, Piwnica-Worms H. Death by releasing the breaks: CHK1 inhibitors as cancer therapeutics. Trends Mol Med. 2011;17(2):88-96.

13. Russell KJ, Wiens LW, Demers GW, Galloway DA, Plon SE, Groudine M. Abrogation of the $\mathrm{G} 2$ checkpoint results in differential radiosensitization of G1 checkpoint-deficient and G1 checkpoint-competent cells. Cancer Res. 1995;55(8):1639-42.

14. Luo Y, Rockow-Magnone SK, Kroeger PE, Frost L, Chen Z, Han EK, et al Blocking Chk1 expression induces apoptosis and abrogates the G2 checkpoint mechanism. Neoplasia. 2001;3(5):411-9.

15. Janetka JW, Ashwell S. Checkpoint kinase inhibitors: a review of the patent literature. Expert Opin Ther Pat. 2009;19(2):165-97.
16. Cazares-Korner C, Pires IM, Swallow ID, Grayer SC, O'Connor LJ, Olcina MM, et al. $\mathrm{CH}-01$ is a hypoxia-activated prodrug that sensitizes cells to hypoxia/ reoxygenation through inhibition of Chk1 and Aurora A. ACS Chem Biol. 2013:8(7):1451-9.

17. Sorensen CS, Hansen LT, Dziegielewski J, Syljuasen RG, Lundin C, Bartek J, et al. The cell-cycle checkpoint kinase Chk1 is required for mammalian homologous recombination repair. Nat Cell Biol. 2005;7(2):195-201.

18. Parsels LA, Morgan MA, Tanska DM, Parsels JD, Palmer BD, Booth RJ, et al. Gemcitabine sensitization by checkpoint kinase 1 inhibition correlates with inhibition of a Rad51 DNA damage response in pancreatic cancer cells. Mol Cancer Ther. 2009;8(1):45-54

19. Morgan MA, Parsels LA, Parsels JD, Lawrence TS, Maybaum J. The relationship of premature mitosis to cytotoxicity in response to checkpoint abrogation and antimetabolite treatment. Cell Cycle. 2006;5(17):1983-8.

20. Myers K, Gagou ME, Zuazua-Villar P, Rodriguez R, Meuth M. ATR and Chk1 suppress a caspase-3-dependent apoptotic response following DNA replication stress. PLoS Genet. 2009;5(1):e1000324.

21. Rodriguez R, Meuth M. Chk1 and p21 cooperate to prevent apoptosis during DNA replication fork stress. Mol Biol Cell. 2006:17(1):402-12.

22. Rodriguez R, Gagou ME, Meuth M. Apoptosis induced by replication inhibitors in Chk1-depleted cells is dependent upon the helicase cofactor Cdc45. Cell Death Differ. 2008;15(5):889-98.

23. Al-Kaabi MM, Alshareeda AT, Jerjees DA, Muftah AA, Green AR, Alsubhi NH, et al. Checkpoint kinase1 (CHK1) is an important biomarker in breast cancer having a role in chemotherapy response. $\mathrm{Br}$ J Cancer. 2015;112(5):901-11.

24. Mitchell JB, Choudhuri R, Fabre K, Sowers AL, Citrin D, Zabludoff SD, et al. In vitro and in vivo radiation sensitization of human tumor cells by a novel checkpoint kinase inhibitor, AZD7762. Clin Cancer Res. 2010;16(7):2076-84.

25. Xiao Y, Ramiscal J, Kowanetz K, Del Nagro C, Malek S, Evangelista M, et al. Identification of preferred chemotherapeutics for combining with a CHK1 inhibitor. Mol Cancer Ther. 2013;12(11):2285-95.

26. Morgan MA, Parsels LA, Zhao L, Parsels JD, Davis MA, Hassan MC, et al. Mechanism of radiosensitization by the Chk1/2 inhibitor AZD7762 involves abrogation of the $\mathrm{G} 2$ checkpoint and inhibition of homologous recombinational DNA repair. Cancer Res. 2010;70(12):4972-81.

27. Wang Q, Fan S, Eastman A, Worland PJ, Sausville EA, O'Connor PM. UCN-01: a potent abrogator of $\mathrm{G} 2$ checkpoint function in cancer cells with disrupted p53. J Natl Cancer Inst. 1996;88(14):956-65.

28. Luo Y, Rockow-Magnone SK, Joseph MK, Bradner J, Butler CC, Tahir SK, et al. Abrogation of $\mathrm{G} 2$ checkpoint specifically sensitize p53 defective cells to cancer chemotherapeutic agents. Anticancer Res. 2001;21(1A):23-8.

29. Zabludoff SD, Deng C, Grondine MR, Sheehy AM, Ashwell S, Caleb BL, et al. AZD7762, a novel checkpoint kinase inhibitor, drives checkpoint abrogation and potentiates DNA-targeted therapies. Mol Cancer Ther. 2008:7(9):2955-66.

30. Chou TC. Drug combination studies and their synergy quantification using the Chou-Talalay method. Cancer Res. 2010;70(2):440-6.

31. Kastan MB, Onyekwere O, Sidransky D, Vogelstein B, Craig RW. Participation of p53 protein in the cellular response to DNA damage. Cancer Res. 1991;51(23 Pt 1):6304-11

32. Lowe SW, Ruley HE, Jacks T, Housman DE. p53-dependent apoptosis modulates the cytotoxicity of anticancer agents. Cell. 1993;74(6):957-67.

33. Carrassa L, Broggini M, Erba E, Damia G. Chk1, but not Chk2, is involved in the cellular response to DNA damaging agents: differential activity in cells expressing or not p53. Cell Cycle. 2004;3(9):1177-81.

34. Ganzinelli M, Carrassa L, Crippa F, Tavecchio M, Broggini M, Damia G. Checkpoint kinase 1 down-regulation by an inducible small interfering RNA expression system sensitized in vivo tumors to treatment with 5-fluorouracil. Clin Cancer Res. 2008;14(16):5131-41.

35. Hunter FW, Wang J, Patel R, Hsu HL, Hickey AJ, Hay MP, et al. Homologous recombination repair-dependent cytotoxicity of the benzotriazine di-Noxide CEN-209: comparison with other hypoxia-activated prodrugs. Biochem Pharmacol. 2012;83(5):574-85

36. Hunter FW, Hsu HL, Su J, Pullen SM, Wilson WR, Wang J. Dual targeting of hypoxia and homologous recombination repair dysfunction in triplenegative breast cancer. Mol Cancer Ther. 2014;13(11):2501-14.

37. Jeggo P, Lobrich M. Radiation-induced DNA damage responses. Radiat Prot Dosimetry. 2006;122(1-4):124-7.

38. Maacke H, Jost K, Opitz S, Miska S, Yuan Y, Hasselbach L, et al. DNA repair and recombination factor Rad51 is over-expressed in human pancreatic adenocarcinoma. Oncogene. 2000;19(23):2791-5. 
39. Bahassi EM, Ovesen JL, Riesenberg AL, Bernstein WZ, Hasty PE, Stambrook PJ. The checkpoint kinases Chk1 and Chk2 regulate the functional associations between hBRCA2 and Rad51 in response to DNA damage. Oncogene. 2008;27(28):3977-85.

40. Huang M, Miao ZH, Zhu H, Cai YJ, Lu W, Ding J. Chk1 and Chk2 are differentially involved in homologous recombination repair and cell cycle arrest in response to DNA double-strand breaks induced by camptothecins. Mol Cancer Ther. 2008;7(6):1440-9.

41. Wang Y, Decker SJ, Sebolt-Leopold J. Knockdown of Chk1, Wee1 and Myt1 by RNA interference abrogates $\mathrm{G} 2$ checkpoint and induces apoptosis. Cancer Biol Ther. 2004;3(3):305-13.

42. Oza V, Ashwell S, Almeida L, Brassil P, Breed J, Deng C, et al. Discovery of checkpoint kinase inhibitor (S)-5-(3-fluorophenyl)-N-(piperidin-3-yl)-3ureidothiophene-2-carboxamide (AZD7762) by structure-based design and optimization of thiophenecarboxamide ureas. J Med Chem. 2012;55(11):5130-42.

43. Bartucci M, Svensson S, Romania P, Dattilo R, Patrizii M, Signore M, et al. Therapeutic targeting of Chk1 in NSCLC stem cells during chemotherapy. Cell Death Differ. 2012;19(5):768-78.

44. Parsels LA, Qian Y, Tanska DM, Gross M, Zhao L, Hassan MC, et al. Assessment of chk1 phosphorylation as a pharmacodynamic biomarker of chk1 inhibition. Clin Cancer Res. 2011;17(11):3706-15.

45. Ward IM, Chen J. Histone H2AX is phosphorylated in an ATR-dependent manner in response to replicational stress. J Biol Chem. 2001;276(51):47759-62.

\section{Submit your next manuscript to BioMed Central and take full advantage of:}

- Convenient online submission

- Thorough peer review

- No space constraints or color figure charges

- Immediate publication on acceptance

- Inclusion in PubMed, CAS, Scopus and Google Scholar

- Research which is freely available for redistribution 